\title{
JULES MASSENET'S BALLET “LA CIGALE”: A NEW PERSPECTIVE OF AN OLD FABLE
}

\begin{abstract}
Annotation. The object of the research of the article is Jules Massenet's ballet "La Cigale," which is examined, on the one hand, as one of the composer's works in the indicated genre (Massenet wrote three ballets) and, on the other hand, as an example of French ballet music of the turn of the $19^{\text {th }}$ and $20^{\text {th }}$ centuries. A certain amount of decline in the indicated period of Western European ballet as a phenomenon related to theater, that revealed itself primarily in the sphere of production and performance, paradoxically, did not affect its musical side, which is cindicated both by the multitude of the musical scores composed and the large number of composers writing them (Gabriel Pierné, Reynaldo Hahn, Edouard Lalo, Camille Saint-Saens, André Messager, Fules Massenet and others). Upon analyzing the ballet "La Cigale" the author of the article, in light of the multifaceted aspect of the issue, used a complex approach uniting the methods of historicity, literary criticism, analytical musicology and source studies. The conclusions of the work are formed by the revealed peculiarities of interpretation and rethinking of the plot used (Jean de La Fontaine's fable "La Cigale et la Fourmi," known in Russia as "The Dragonfly and the Ant"), the description of the inner structure of the ballet's music (a through development with several relatively completed dancing episodes appearing during the process), the indication of the details of the musical solution (usage of the leitmotif and recurring musical fragments, musical quotations, as well as the sound of the chorus brought into the ballet's finale). The novelty of the work consists in the comprehensive analysis of a ballet by Massenet carried out for the first time and incorporating it into the number of the few researched ballet scores by the French composers of the turn of the $19^{\text {th }}$ and $20^{\text {th }}$ centuries.
\end{abstract}

Keywords: Jules Massenet, Jean de la Fontaine, fable, La Cigale et la Fourmi, reevaluation, divertimento-ballet, dance, leitmotif, musical quotation, sound depiction.

The end of the $19^{\text {th }}$ and beginning of the $20^{\text {th }}$ century presented a complex and ambivalent period in the history of the ballet theater of France. On the one hand, researchers indicate not unfoundedly that this period "comes under the sign of a decline of Western European ballet theater."1 On the other hand, it must be acknowledged that the choreographic theater of that time period (first of all, the French theater) could boast of a large quantity of compositions with the most diverse subjects, written by professional composers. Despite the fact that some of them are little known to the general public, they cannot be classed with one stroke of the pen as pertaining to the category of "juror musicians $s^{2}$, working only in one category of genre, whose works have been traditionally subject to criticism. The composers of ballet from the indicated epoch include Gabriel Pierné, Reynaldo Hahn, Edouard Lalo, Camille Saint-Saens, André Messager and, of course, Jules Massenet.

Slonimsky, Yu. Dramaturgiya baletnogo teatra XIX veka. Ocherki. Libretto. Stsenarii. [Dramaturgy of $19^{\text {th }}$ Century Ballet Theater. Essays. Librettos. Scenarios. - Moscow: Iskusstvo, 1977._- p. 227.

A definition used broadly among musicologists of the $20^{\text {th }}$ and 21 st centuries for composers whgo write exclusively ballet music
In Massenet's musical legacy ballets do not pertain to the most broadly known compositions, yielding by far in their popularity to operas and only rarely, in passing, are mentioned in works of art criticism. Nonetheless, three musical works written by the composer for the choreographic theater remain of interest for researchers. First of all, this is due to the music, written by a significant French composer from the $19^{\text {th }}$ and $20^{\text {th }}$ centuries and, moreover, the libretto pays tribute to various tendencies of plots that had emerged in Western European ballet towards the end of the $19^{\text {th }}$ century.

All three of these compositions were written at the turn of the $19^{\text {th }}$ and $20^{\text {th }}$ centuries, and all three of them are connected with different scenario traditions.

The first ballet — "Le Carillon" (composed in 1892) contains a plot that is simultaneously a real-life story (with fantastic elements), comedy and semi-historical, while the third, "Espada" (written in 1908), is a work in the vein of romantic Spanish exoticism, recounts about the love and death of a toreador, presenting a continuation of the vein of "exotic" Spanish ballets characteristic for the genre in the $19^{\text {th }}$ century. Both

\footnotetext{
Sometimes in sources in Russian one can find the ballet with the title of "Toreodor."
} 
compositions are based on original librettos by various writers. The second ballet in its chronology, "La Cigale" (composed in 1904) manifests an example of a composition the plot of which is based on a literary work. However, it is based not on a novelette, novel, short story or fairy tale, but on a fable. Massenet's "La Cigale" presents a transformation of the famous fable by Jean de La Fontaine, the original title of which is "La Cigale et la Fourmi," while in Russia is more wellknown in the version of Ivan Krylov with the title "The Dragonfly and the Ant."

This choice of the literary genre incorporated for the ballet stage, quite singular upon first glance, is in fact not very original. Ballet composers had previously turned to fables as sources for plots, moreover, it was an experience pertaining to the Romantic era and likewise presenting a version of one of La Fontaine's tales'. An example of this was the ballet "La chatte metamorphose en femme" ["The Cat Transformed into a Woman"], which was presented in 1837 on the stage of the Paris Opera theater by choreographer Jean Corally with the music of Alexandre Montfort.

However, it must be specified that by 1904, when Massenet started his work on the ballet, the fable "La Cigale et la Fourmi" had already had its history of stage manifestation as Edmond Audran's "La Cigale et la Fourmi," produced in 1886 at the Jetee Theater, as well as a certain number of instructive plays meant to be staged by children. Thereby, when Massenet turned to this plot, the overall potential for its theatrical production was doubtless. The ballet "La Cigale" was created for production at the Opera Comique in Paris. Its choreography, similarly to that of many other French ballets of that time, was carried out by Madame Mariquita. The musical director of the theater at that time was André Messager, also well-known as a composer of ballet scores, whereas the director of the troupe was Claudio Vicentini, who worked for a certain period of time in Russia and wrote the ballet "Le Phantome du Roi" (1886) for Marius Petipa. Practically everything in this theater was conducive to the appearance of a new choreographic production.

The librettist of "La Cigale," Henri Cain, as mentioned by the researcher of Jules Massenet's music, Yuli Kremlyov, "humanized and modernized La Fontaine's fable2." But the issue was not in that he endowed his protagonists with human images, which would be natural in ballet. This libretto presents a most curious

In this context, it must be reminded that the fables of the French poet, similarly to some of the fables of Krylov, present different versions of the fables of Aesop, linked with translation and adaptation for a concrete epoch and a concrete culture.

Kremlyov, Yu. Jules Massenet.- Moscow: Sovetsky kompozitor. 1969. - p. 187. version of a new interpretation of what seemed to be a fable well-known to everybody from childhood.

Two characters are present in Massenet's ballet, named particularly as such: "La Cigale" [the Cricket] and "Madame Fourmi" [Madame Ant] 3 . In one of the episodes the kindhearted cricket becomes surrounded by an entire corps-de-ballet of her friends, who are also labeled "crickets," which cannot but arouse memories of the tradition of romantic ballet, which included, as one example, "La Sylphide" ("The Sprite") as the main protagonist and the sprites as a generalized protagonist. In addition, for the sake of developing the subject and greater theatrical development, the author brings additional characters into the intrigue of the plot: the Cricket's Beloved, a Bank Teller and the Poor Girl ("la Pauvrette"). Their interrelations not only bring in complementary elements to the well-known fable, but also reevaluate to a considerable degree the plot, placing totally different accents into it.

Prior to continuing the overview of this ballet, we shall present as short synopsis of it, without which it is virtually impossible to understand the work:

The first act of the ballet narrates of a spring day of the Cricket ("La Cigale"). Gentle and responsive in her nature, she is ready to give to others everything she has. She gives her breakfast, her hood, her umbrella and her last money to the Poor Girl ("La Pauvrette"), who is cold and hungry, she gives the pie that she baked to Madame Ant ("Madame Fourmi"), who is hurrying to mass and is detained on the way by a fabulous aroma, and herself breakfasts on dry bread and a glass of water. The Cricket lightheartedly tears up into papillotes the promissory note brought by the Bank Teller, and the last thing she has left - a kiss - she gives to her Beloved.

The Second Act passes the scene into harsh winter. After Christmas Mass, Madame Ant returns home bundled up warmly and with an umbrella, while the Cricket dressed in a costume of a dancer and holding a guitar is suffering from the cold weather and the wind. She knocks on the door of Madame Ant and asks for shelter, but the latter drives her away with a broomstick, repeatedly telling her: "Go, dance!" The Cricket, driven away, sees her former Beloved and the previous Poor Girl adorned in a bonnet received by her as a gift, both laughing and covering themselves with an umbrella. The pair passes by without noticing her. The Cricket dies, clasping in her embraces her sole friend, the guitar. All of a sudden, there is a clap

\footnotetext{
It must be mentioned that in the original text, unlike the customary translation, the fable has two femalecharacters contropposing each other, since both the word for "cricket" (la cigale) and the word for "ant" (la fourmi) in French are feminine.
} 
of thunder, the winds and blizzard disappear, we hear angels singing a lullaby, calling out to the unfortunate Cricket. She stretches out her hands to them, then sees that she has little wings grow on her back, and joins the "heavenly games" of the angels: "Come to us, Cricket, little thing, come to us! We shall comfort you, little despaired sister... your heart was too gentle."

In the ballet version La Fontaine's fable is not merely transformed and "humanized," but its moral ends up being virtually "turned topsy-turvy." The didacticism and extolling of work, initially juxtaposed to inactivity and sloth, turns into a story of a kind-hearted heroine, suffering from her kindness, who is confronted by another heroine, cruel and egotistic, personifying the philistine, sanctimonious element. Due to the inequality of the forces, in their "earthly" confrontation the triumph is achieved by Madame Ant, whereas in the "heavenly" life recompense is awarded particularly to the lightheaded but kind-hearted Cricket, who had suffered plenty on earth.

In the interpretation of the plot one can also see the elaboration of the dramaturgical idea that finds its beginning in the romantic performances of the $19^{\text {th }}$ century, presenting itself as rather unusual in a ballet of the beginning of the $20^{\text {th }}$ century, a time that seems to have departed from the romantic ballet of the previous century. The final scene of "La Cigale" could be perceived as a visible "gesture" to the direction of traditional ballet apotheoses, where the heroes, having passed through the outer impediments and inner sufferings, are reunited in a certain "other world." Incidentally, in "La Cigale" an overt love story is absent: having begun in the First Act, it quickly passes into a narrative of betrayal. Nonetheless, the existence of the reminiscence of the traditional "ideal world" in the final scene of "La Cigale" is doubtless.

On the other hand, the precise indication of the time of the action at the beginning of the second act (Christmas) and the presence in the final scene of an invisible chorus, not merely of some sorts of abstractive "sprites," "spirits" or "fairies," but of "angels," brings in associations of another kind, not at all connected to musical theater. Here we can also speak of a peculiar interpretation of the tradition of the Christmas story. If we examine the libretto of "La Cigale," turning away from both the overall genre of the work (namely, the ballet) and of its literary source (a fable), it will turn out that we have before us a version of a Christmas story, in which the good necessarily triumphs, while all the misfortunes suffered by the heroine end up by

Here and below the commentaries and stage directions of the piano-vocal score (La Cigale. Divertissement Ballet en deux actes de Henri Cain. Musique de J. Massenet. — Paris: Au Ménestrel, 1904. _ 88 p.) are cited in translation of the author of the article. merely leading to the path towards the ideal world of the final scene.

Noteworthy of special attention in this case is the image of Madame Ant, who personifies by herself not merely petty bourgeois philistinism, traditionally juxtaposed to the romantic spirit, but can also be interpreted as a type of the sanctimonious heroine. Each of her appearances on stage is invariably connected with display of outward religiosity: in the First Act she is on her way to mass, when she is drawn back by the remarkable aroma of the Cricket's baked goods, in the Second Act she turns out the unhappy heroine from her doorstep immediately after returning from Christmas mass.

Thereby, it turns out that Cain, having approached the fable as an overall foundation, which may be interpreted very freely, literally "drew in" on this familiar canvas new images, replacing the old ones, having added unusual semantic color, and this resulted in a libretto, outwardly based on the $17^{\text {th }}$ century text, however, containing in itself rather a romantic basis.

Massenet interprets the genre of the ballet as a "divertimento ballet" ("Divertissement Ballet en deux actes"), and, most likely, with this definition it is possible to explain the special features of his musical construction. Let us examine consistently the structure of the ballet, its dance numbers, leitmotifs and recurring musical fragments, orchestral episodes and all other curious musical "details" of this composition.

Similarly to the composer's other ballets each act of "La Cigale" is constructed as a single sounding canvas, without any detailed subdivision into customary ballet numbers. It must be said that Massenet conceives of this composition as having an inward division and inner logic of development, and thereby, without specifying this in any way in the musical text itself, nonetheless, presents a list, in the beginning of the ballet, of the fragments that comprise it logically ${ }^{2}$, not written down in the musical text.

Massenet deviates from this rule only three times. In the First Act he indicates especially the "Rondo of Crickets," labeling the beginning of the Second Act (carrying the function of an introduction and functioning in itself as a symphonic poem) as an "Interlude" and placing into the same Act a "Whirling Waltz of Winds," displaying a peculiar dramatic culmination of the theatrical composition. There are no other number indications in the musical score besides that.

This may appear strange upon first glance. However, if we familiarize ourselves more closely with

First Act: Prelude, the Cricket sleeps, the Cricket's Awakening, the Cricket dressing herself, the Poor Girl, Rondo of the Crickets, Madame Ant, the Bank Teller, the Divine Kiss. Second Act: Interlude, Christmas Mass, Whirling Waltz of the Winds, « Open the Door for Me » (variations), Death of the Crickets, Lullaby of the Angels. 

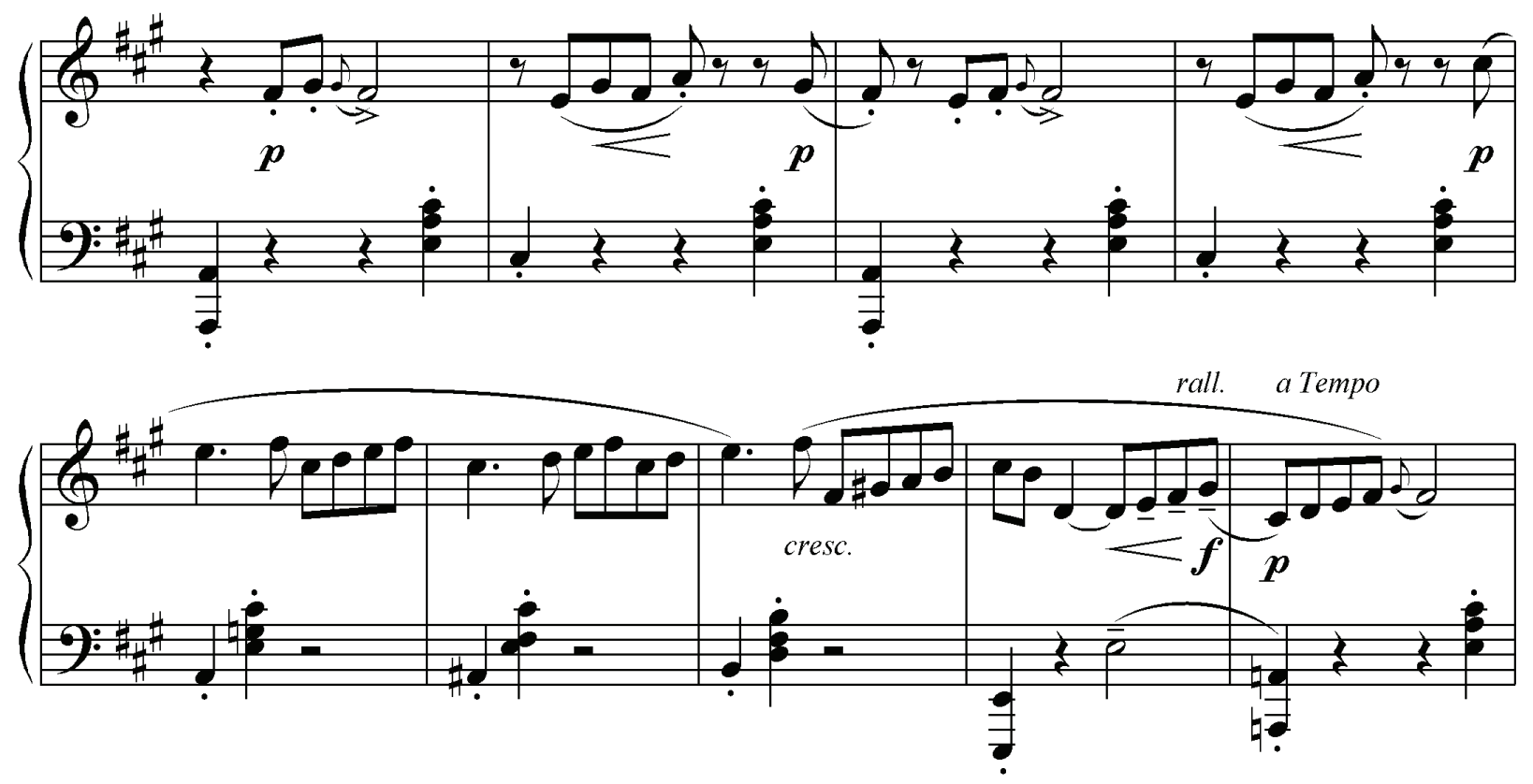

Fig. 1

the music of the ballet, we can come to the conclusion that the term "divertimento" correlates best of all with its inner structure. Notwithstanding its unity, most of the fragments indicated by Massenet carry in themselves the attributes of various dance forms, in one way or another. Whether or not we are able to specify precisely to which genre each fragment pertains, or whether we can allow ourselves merely to ascribe a certain overall dance-like quality of the music's overall motion, in any case, this peculiar feature conveys the first and foremost impression that we are left with after becoming more familiar with the music. Most likely, having this in mind, Massenet avoids writing large-scale pantomimic scenes, because for the sake of development of the plot he makes use of various fragments of dance movements of diverse characters united into an integral whole by very short transitional passages. There are very few episodes in which the "dance spirit" is missing, and those are connected, first of all, with the "character who does not dance" (Madame Ant), who is characterized in them by her own musical theme, which we shall present later.

We can likewise characterize as devoid of dance quality the few "orchestral" episodes not pertaining directly to the action (the Prelude, Interlude and, in part, the variations to "Ouvre moi ta porte") and serving totally different laws, having solely to do with musical development, and not with the theatrical action.

However, let us first turn to those fragments which, not indicated directly in the musical score as dances, nonetheless, bear its attributes. There are many such episodes, but most interesting among them are the ones in which the genre indications of dances are slightly eroded and their indication seems somewhat paradoxical.

For example, in the scene "The Cricket's Awakening," despite its quadruple measure, there is a feel of waltz motion, albeit, slightly transformed and transfigured, but still inferred (Fig. 1).

However, more often than not the dance genre turns out to be more than definite, and in most cases it represents waltzes, expounded in various versions (first of all this pertains to the "carefree" First Act; however, there is also a tragic waltz, as well, present in the Second Act).

Among the numerous waltzes describing in one way or other the main heroine, there are two corps-deballet dances, in a certain sense placed in the center of the First and Second Act of the work. It cannot be entirely said that they form the semantic centers of the two acts; however, each of them carries a significant meaning.

In the First Act it is the Rondo of Crickets, which becomes their peculiar hymn, a story about the happy spring life. It is permeated with the joy of life "overflowing" with all the colors of the rainbow, ringing out and singing.

The theme of the first section of the Rondo (here, most likely, we are dealing with a construction similar to the second form of the rondo, i.e. a form with two principal themes) slightly reminds of a polka by the character of its motion. They easily ascend, then descend back just as quickly, and as the result of a lengthy "suspension" on the last note of the phrase the impression is created that this theme is noon-square and slightly "fantastic." The "fantastic" feeling (or that 

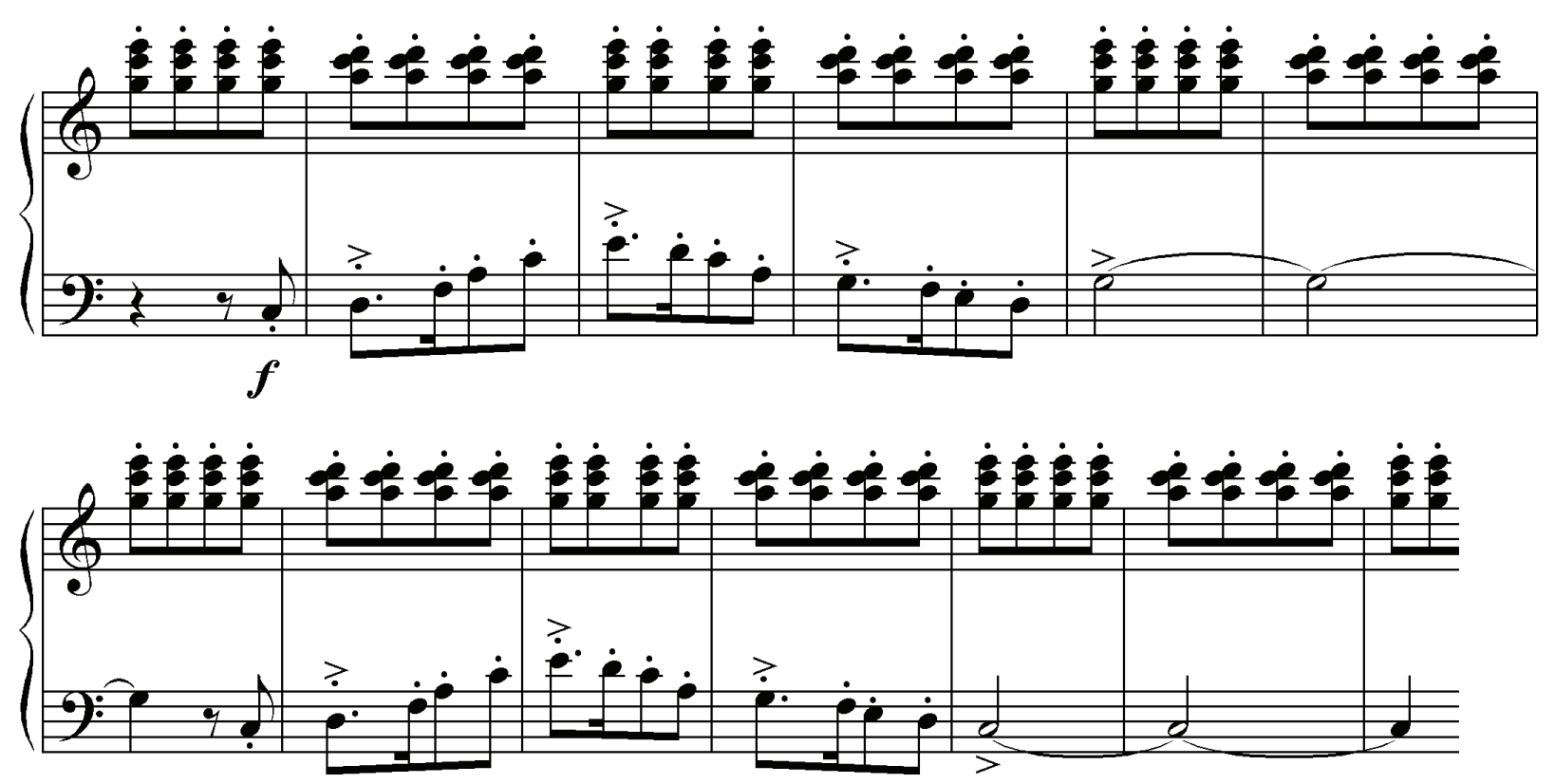

Fig. 2
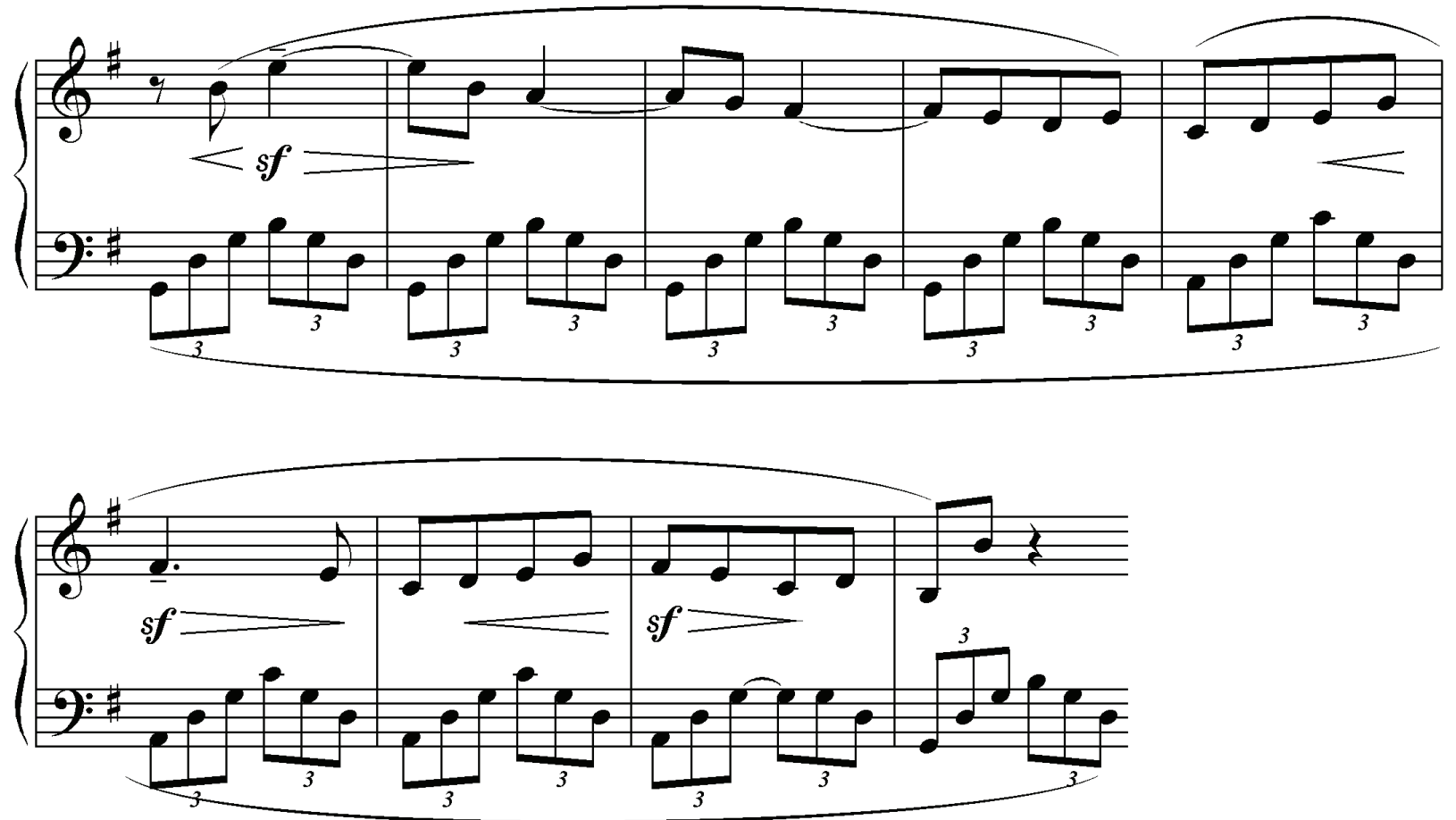

Fig. 3

of a dance-like game) is supported by the accompaniment, which Massenet places in the high sonorous register (Fig. 2).

The middle section of the dance contrasts with the outer sections and, when compared with the main theme, seeming to prance along, carries the image of a vocal lyrical construction, which is enhanced to a great extent by both the suaveness of the melodic line with existent suspension on the strong beat and the accompaniment, reminding of gently gliding waves (Fig. 3). 


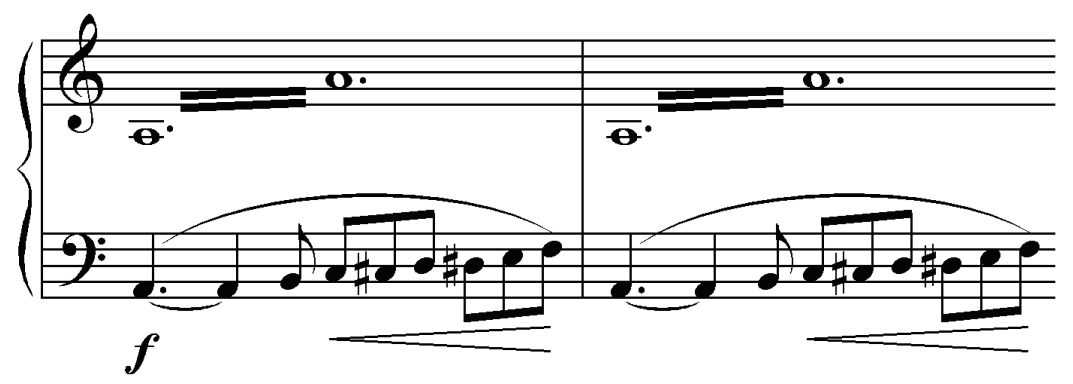

Fig. 4
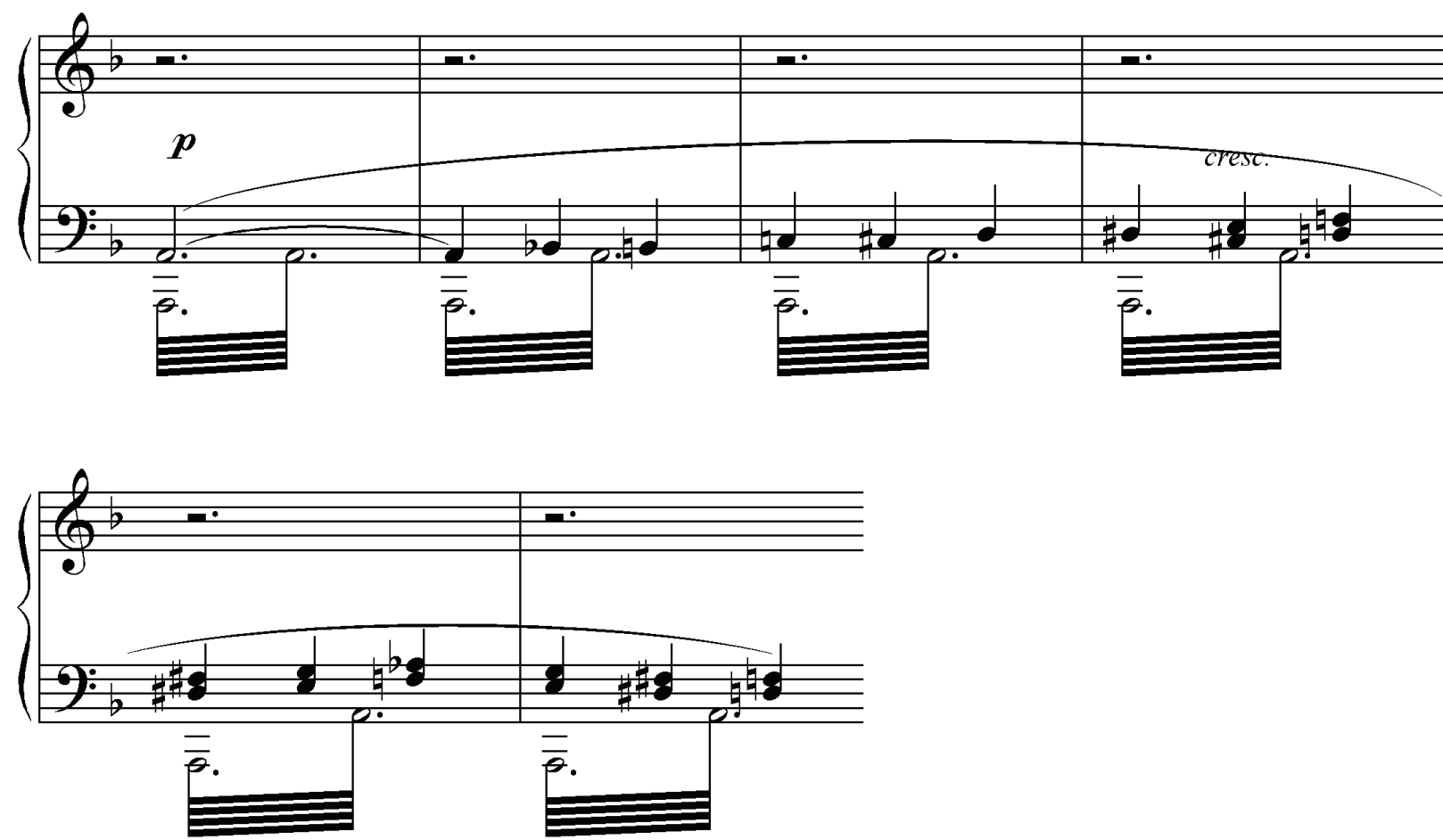

Fig. 5

Unlike many other dances in Massenet's ballet, which as a rule have precise beginnings, and even exact titles in the text of the score, the "Rondo of Crickets" is strictly bound by the frameworks of form and finishes off in a logical manner, creating the impression of a certain "inserted" dance number within the First Act with its free development.

The second dance, situated in the middle of already the Second Act, is the Whirling Waltz of Winds. In counterbalance to the carefree sounding Crickets' Rondo heard in the First Act, this dance is relentless and frightening, recounting about the cruel winter, inevitably replacing the spring. At the same time this is also a symphonic poem about the blizzard in the midst of which the unfortunate Cricket finds herself, as well as the Dance of Winds and Snowflakes per se. Unlike the Crickets' Rondo, it does not contain fixed boundaries, notwithstanding the indication in the score, taking up a much greater amount of musical space than it is even presumed by the list of musical fragments determined for the occasion by Massenet. Its main theme is generated from sonic depictive chromatic motion (appearing long before the beginning of the Waltz proper), which must serve as an illustration to the erupted blizzard. To create this effect, the composer makes use of simple and very expressive means, familiar in many other works of various epochs: tremolos and menacingly sounding ascending chromatic scales in the low "rumbling" register (Fig. 4).

Then, already in the beginning of the Waltz, this chromatic movement becomes rhythmically more monotonous, however, its "assertive power" is augmented, and the tremolo is already utilized not in a tonic octave, but in a dominant harmony in the bass, thereby harbin- 

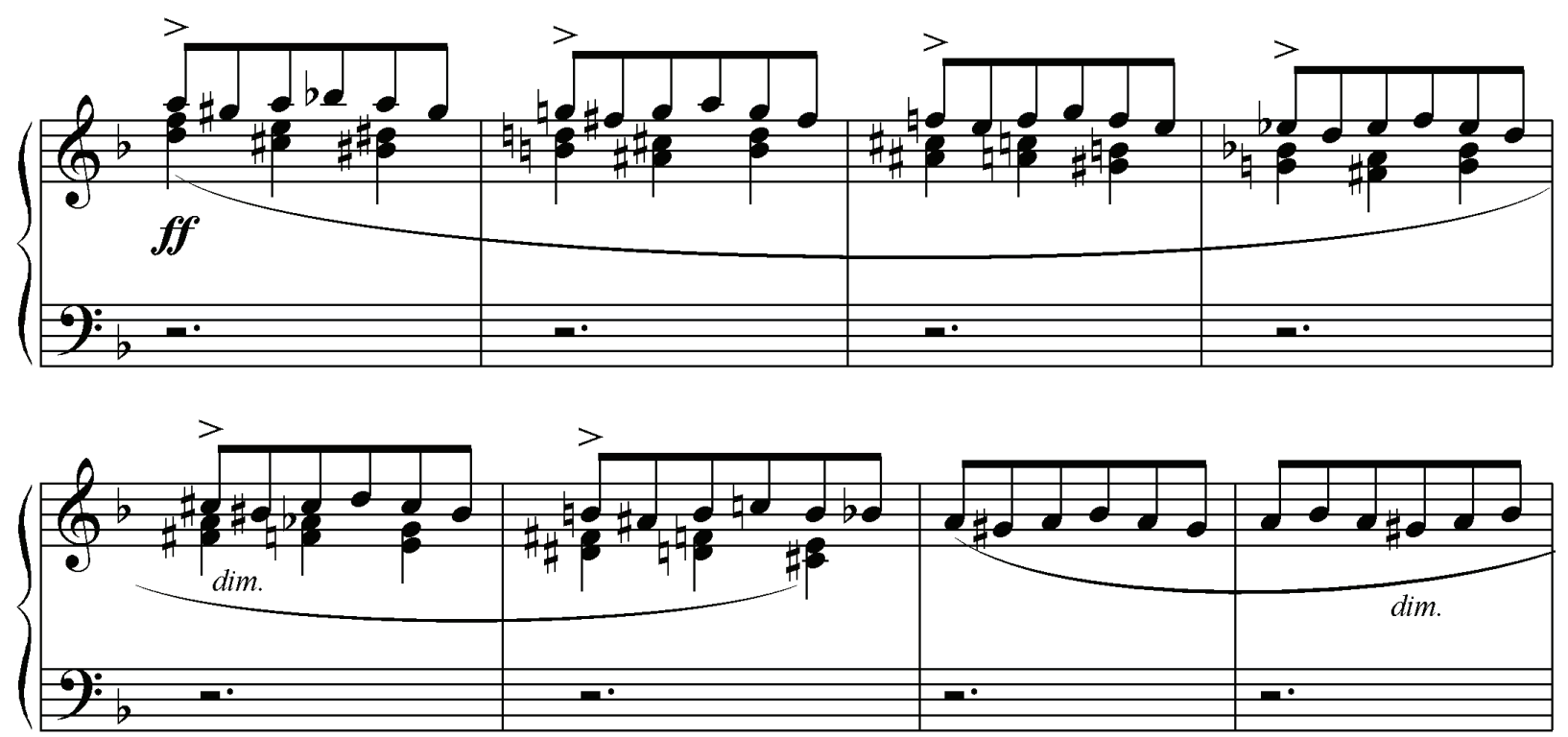

Fig. 6

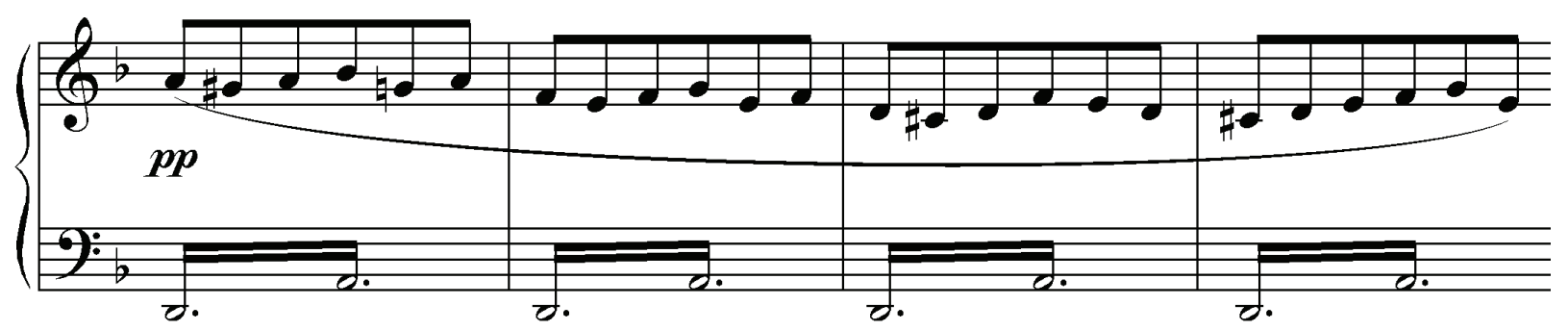

Fig. 7

gering the beginning of the theme (Fig. 5) and, finally, after yet another version of transformation from a chromatic scale into a certain circling whirlwind (Fig. 6), out of this musical "blizzard" the theme proper of the Waltz manifests itself. It absorbs into itself all the attributes that had gradually "gathered" during the course of all the time preceding it, being simultaneously chromatic and whirling, resting on a tremolo of a tonic fifth, as it was in the scene of the blizzard (Fig. 7).

This Waltz begins as a type of rondo, in which there are even two contrasting episodes manifesting themselves. However, subsequently, when the corps-de-ballet dance passes onto a dance episode accompanying the pantomimic scene (that is, when virtually the dance, without stopping in its motion, is reexamined into an active scene), the composer stops maintaining the form, combining the already sounded musical themes in that succession and in those scopes that he feels necessary in the concrete situation of the plot.

The first episode is no less important from a musical or stage perspective than the refrain: it is another waltz, but a much more tempestuous and tragic one, than the dejectedly wailing first one. This theme resembles a despairing cry amidst a hostile nature (Fig. 8).

The second episode, contrasting and paradoxically presenting a major tonality, describes "the pleas of the Cricket to the whirling winds, which oppress it." These please still preserve seemingly with their last efforts the melodicism already familiar from the First Act, but the unexpected accents and the lowered steps accentuated by them constantly "remind" us of the first themes of the Whirling Waltz (Fig. 9).

As we have stated before, subsequently the Waltz becomes subservient to already rather different laws of musical drama, differing from those of the musical form proper, and for this reason its completion is diffused and is stipulated by the development of the subsequent action.

The genre of the ballet-divertimento (or, if one is to cite precisely the genre-related definition of the composition, the "divertimento-ballet), in all likelihood, is also manifested by the fact that in this composition there are practically no leitmotifs present, which can be found in Massenet's other ballets, though in small quantities. The divertimento as a "scheme" for the creation of the 

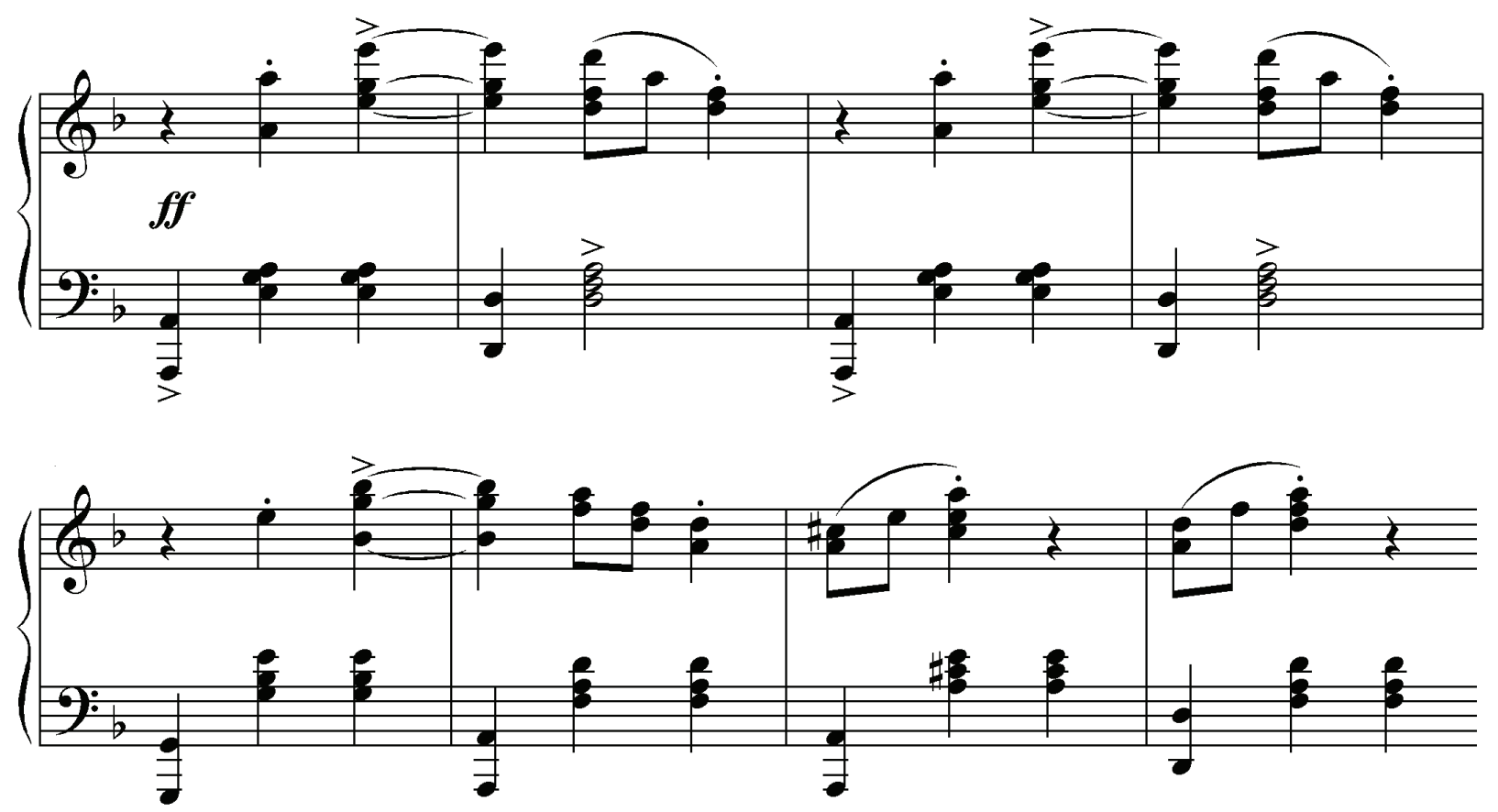

Fig. 8

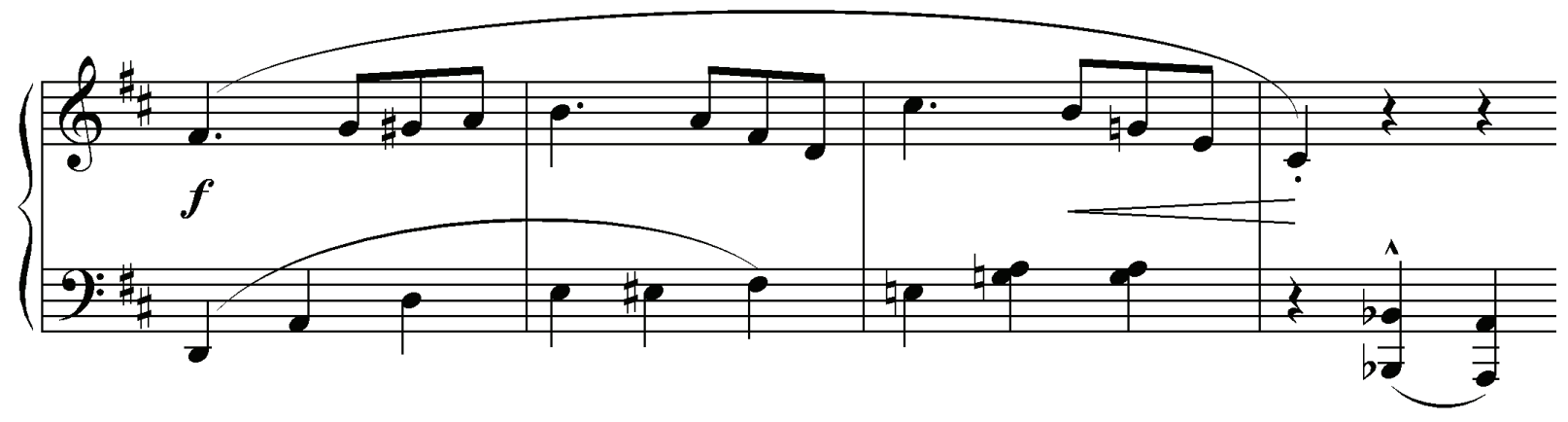

Fig. 9

ballet carries the effect of a certain discreteness of the score, not presuming any large-scale musical unity for the composition. However, in "La Cigale" there can be found one leitmotif, which characterizes one of the heroines - it is the theme of Madame Ant.

Several reasons for this choice of the theme of the second heroine could be found, but one may be counted as preferable for us: Madame Ant is, on the one hand, one of the two main protagonists of the ballet, and on the other hand, presents a pantomimic role. For this reason, her image cannot be fully disclosed in the numerous dance episodes, as it happens with the image of the Cricket, and requires a different means for depiction.

The theme is presented both in the First and in the Second Act, constantly accompanying its "mistress." From one appearance to the next, its character and manner of statement changes, but the main semantic content does not change. This musical "portrait" is apparently connected with the outward appearance of Madame Ant: she is confident of herself and possesses the tendency of catechizing; hence one single repeated pitch seems to "shake a finger" at the injudicious Cricket (Fig. 10).

This theme displays itself most vividly in the Second Act, where it follows its "mistress" literally "at its heels." First it entwines into the sound of the blizzard, when Madame Ant returns from Christmas, then turns into a peculiar climax of this musically descriptive scene (Fig. 11).

However, the theme achieves its greatest intensity at the moment when this character "runs towards the Cricket, as a true harpy, driving her away with sweeps of the broom." Here the theme becomes menacing and harshly accented, as if portraying the strokes of that selfsame broom (Fig. 12). 


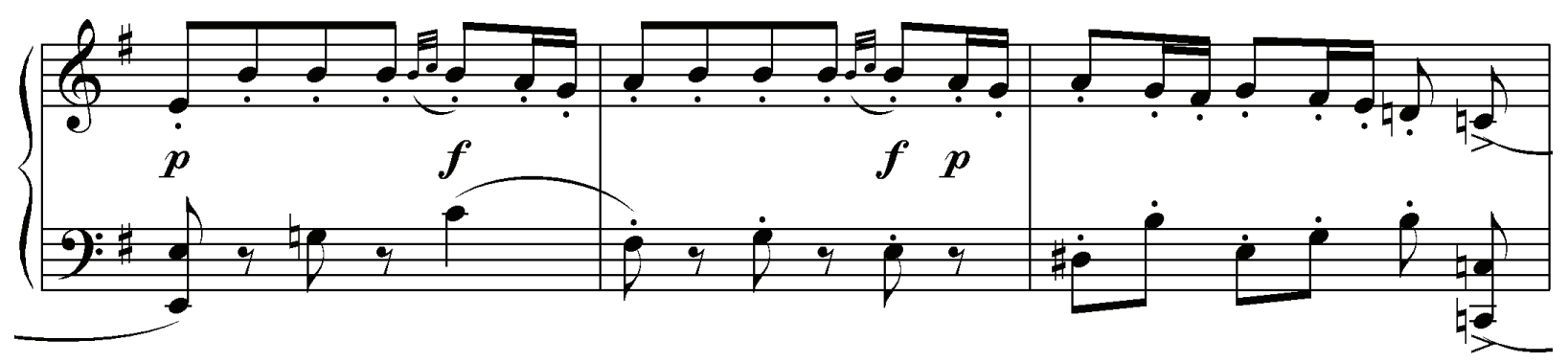

Fig. 10

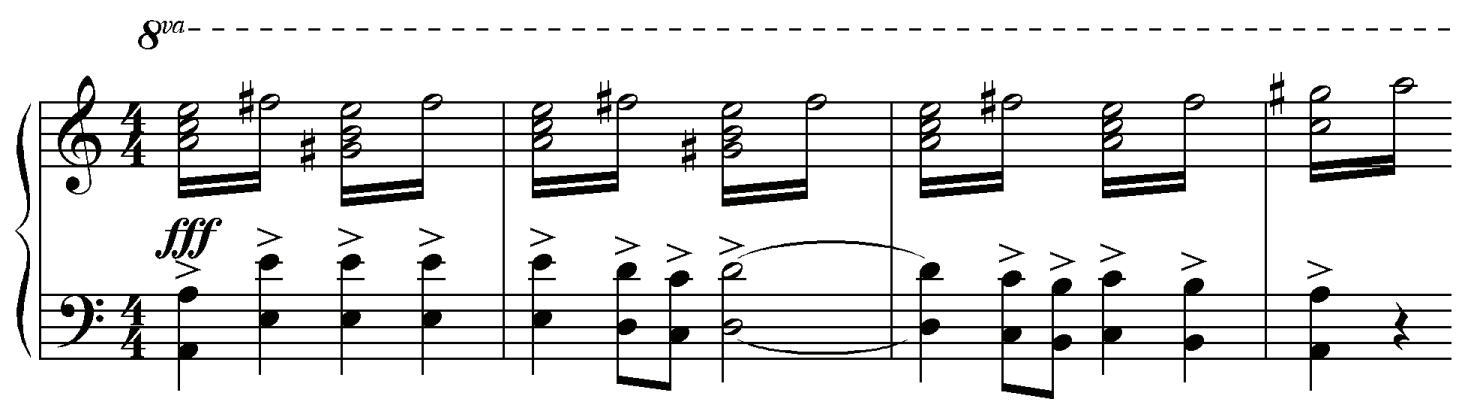

Fig. 11

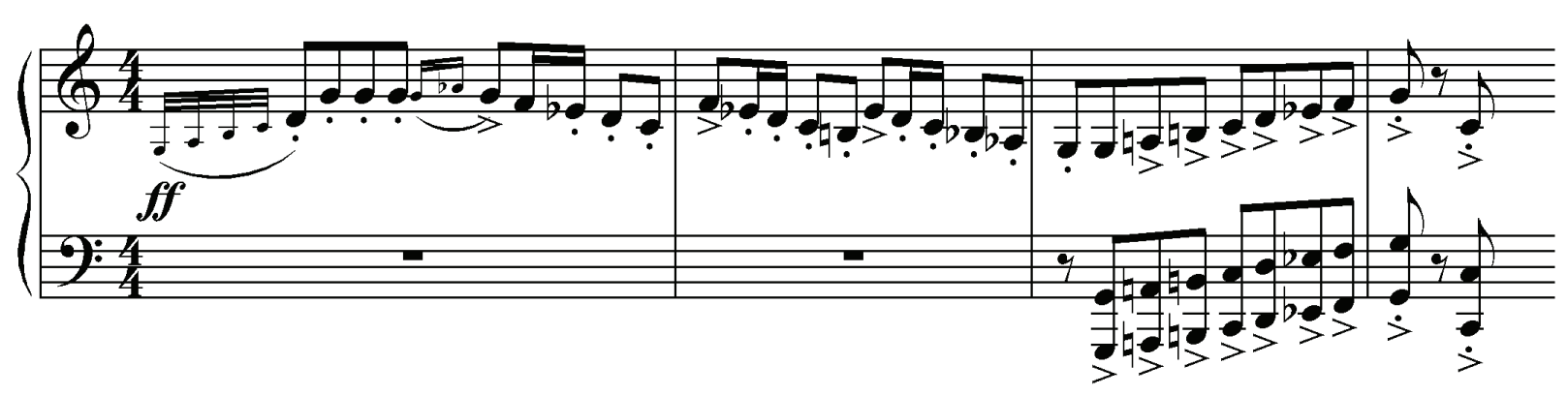

Fig. 12

We cannot find any more leitmotifs in "La Cigale." However, we can observe another interesting means of uniting the musical material within the ballet's divertimento-like construction: the brief, passing recurrences of the motives of the dances from the previous episodes in the short active transitions or in the subsequent episodes. Such a practice does not generate leitmotifs, but it helps Massenet unite the emerging contrasting and thematically vivid fragments within his small musical score. Most frequently, these kinds of "reminiscences" apply to the adjacent fragments, however, in some cases they are connected with the appearance of dance themes in the various acts of the ballet. For example, the dance of the Cricket's Beloved, reminiscent of a folk tune, after sounding in the First Act, appears in a curtailed form in the Second Act (at the moment when the Cricket sees the Beloved and the Poor Girl, who have completely forgotten about her).
This dance can be heard as a marked contrast to all the light, graceful dance forms that characterize the Cricket and her friends. Indeed, it does carry elements from artless folk tunes with pure "square" rhythms and ostinato accompaniment (Fig. 13).

Special mention must be made of the few orchestral episodes, which are not connected directly with the dances, but either present musically descriptive fragments, or possess the character of introductions.

We have already mentioned one of the examples of musical depiction carried out by Massenet in this ballet: it is the scene of the blizzard, inconspicuously passing onto the Whirling Waltz. However, in addition to this rather extensive scene, other, more "small-scale" but not less interesting details may be found.

At the very beginning of the ballet, in full correspondence with his commentaries, the composer "notates" by musical means a cuckoo in a clock, which 


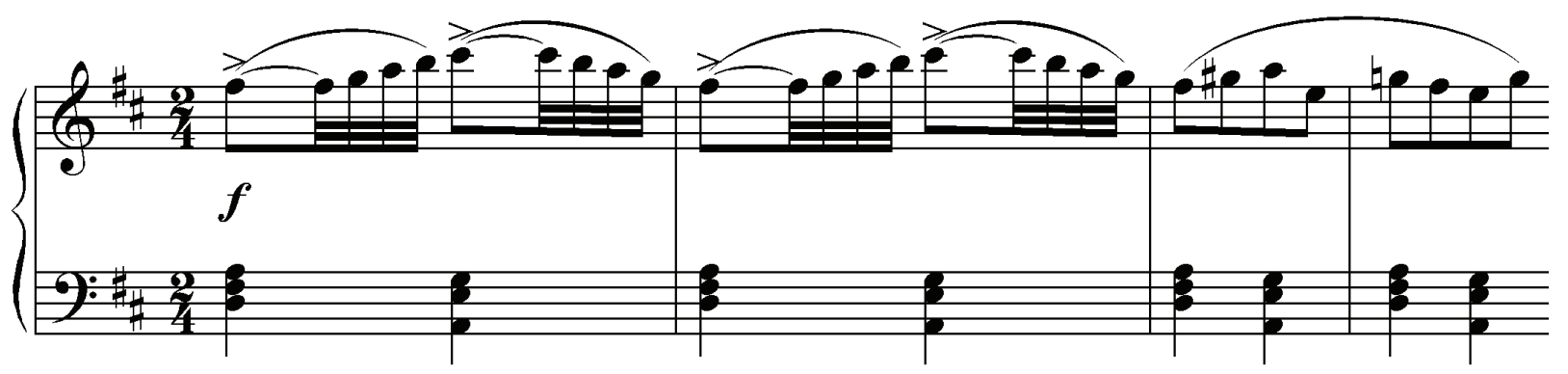

Fig. 13

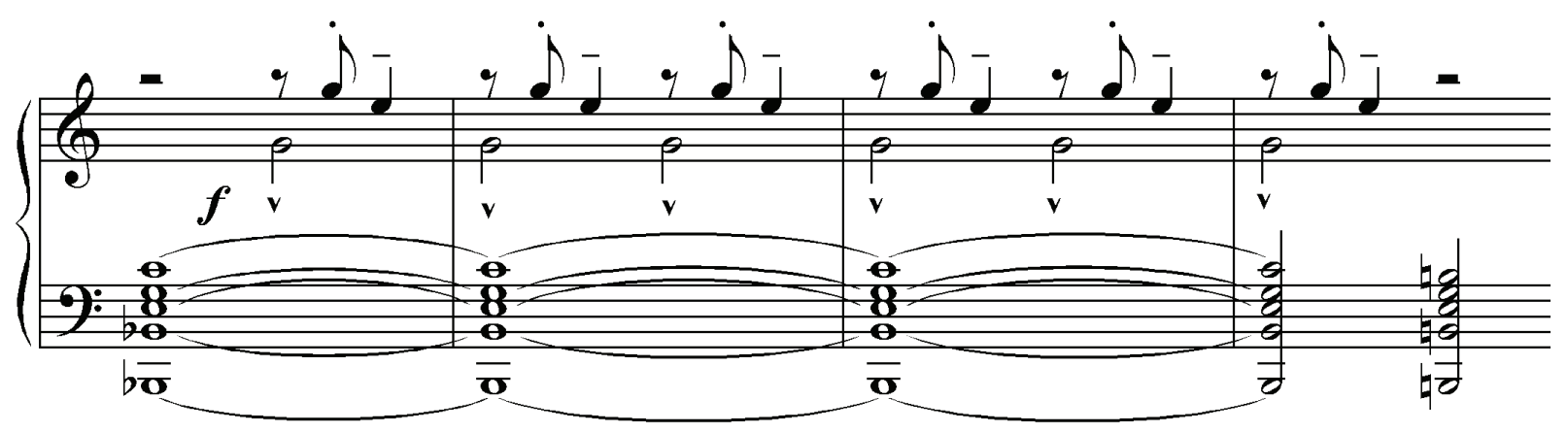

Fig. 14

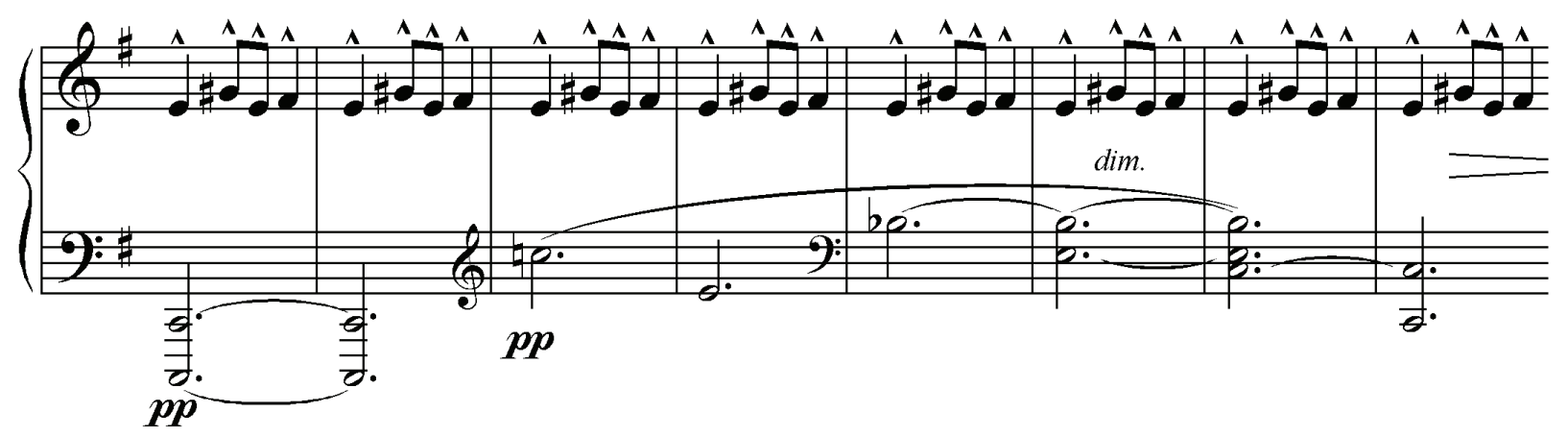

Fig. 15

spells out the beginning of the morning for the Cricket (Fig. 14).

In the episode of "Madame Ant" distant bells are heard, proclaiming the beginning of the mass (Fig. 15).

Two large, extended orchestral introductions to the Acts (the Prelude and the Interlude) are also very interesting in their structure, as well as in the composer's approach to interpreting these orchestral episodes.

The Prelude presents a sound "picture," illustrating a certain natural landscape, which is meant to serve as the background to the First Act. Suggesting light strumming of the strings of the "golden harp," this episode is entirely built on the effects of diatonic sound simultaneously "folded up" into ninth and eleventh chords and "unfolded" into a melodic progression (Fig. 16).

The Interlude, opening up the Second Act (or, to be precise, connecting both Acts into one unified whole, as the title suggests) carries the subtitle "Vieux Noël', demonstrating that for its creation the composer made use of the theme of one of the French Christmas songs. This is done intentionally: the time of the action of the Second Act is Christmas, and the Interlude leads us in a natural way into its musical world. However, the theme chosen by Massenet is in a minor tonality, which somewhat lessens the impact of the initial festive character of the Interlude (Fig. 17).

Massenet composed this episode as a succession of the most diverse variations. The first variation presents a freely interpreted fugato (Fig. 18).

Next comes the second variation in the relative major tonality with a slightly transformed theme,

Literally translated as "Old Christmas" 

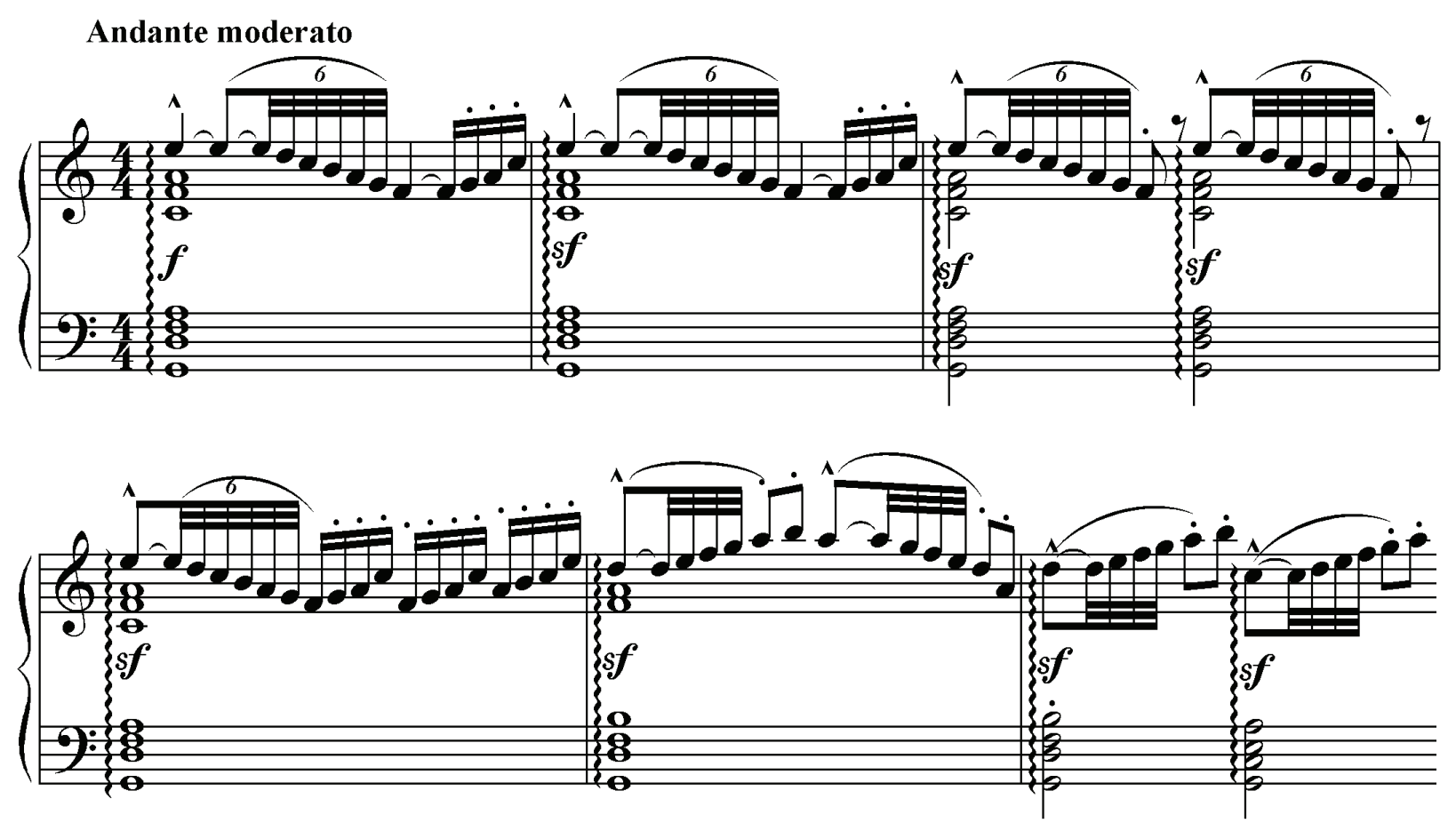

Fig. 16

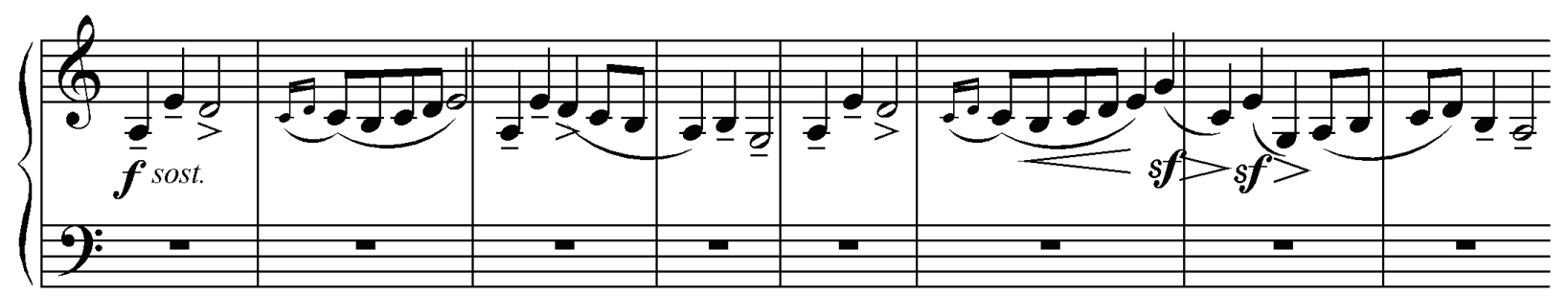

Fig. 17

changing the type of exposition from a contrapuntal to a homophonic one, based on chords (Fig. 19).

The third variation also presents chords and is ceremonial in its character, resembling a majestic hymn (Fig. 20).

The following two variations follow, in one way or another, the "paths" of development already previously indicated providing either a "linear," contrapuntal variant (in the fourth variation), or a "vertical" variant (in the fifth variation). The sixth variation is distinct with a most interesting harmonization of the melody based on numerous seventh chords and brings in additional complexity to the minor-keyed theme by its numerous deviations into major tonality (Fig. 21).

The final, seventh variation resembles a coda, where the theme in augmentation seems to dissolve into an overall chord sound with constantly appearing accompanying voices based on its motives (Fig. 22).

It must be added that whereas the Prelude is not self-contained and naturally passes into the first epi- sode of the First Act ("The Cricket Sleeps"), the Interlude, compared with the other musical fragments, appears almost as a complete work in itself, since only the last sound "impression" from it - an octave tremolo on the tonic - passes onto the scene of the blizzard, changing to a tremolo on the dominant.

It must be acknowledged that the Interlude does not comprise the sole set of variations placed by Massenet into his ballet. Whereas in the previous example we dealt with an orchestral episode preceding the action, the case of a dance number constructed in the form of variations presents itself as a rather rare occurrence'. It sounds at the moment when the Cricket, having knocked at the door of Madame Ant on Christmas night, expects that it would be opened and "plays for her [Madame Ant - A.G.] while dancing."

Besides the example written by Massenet, we can remember the "Slavic Theme and Variations" written by Leo Delbes in his "Coppelia." 

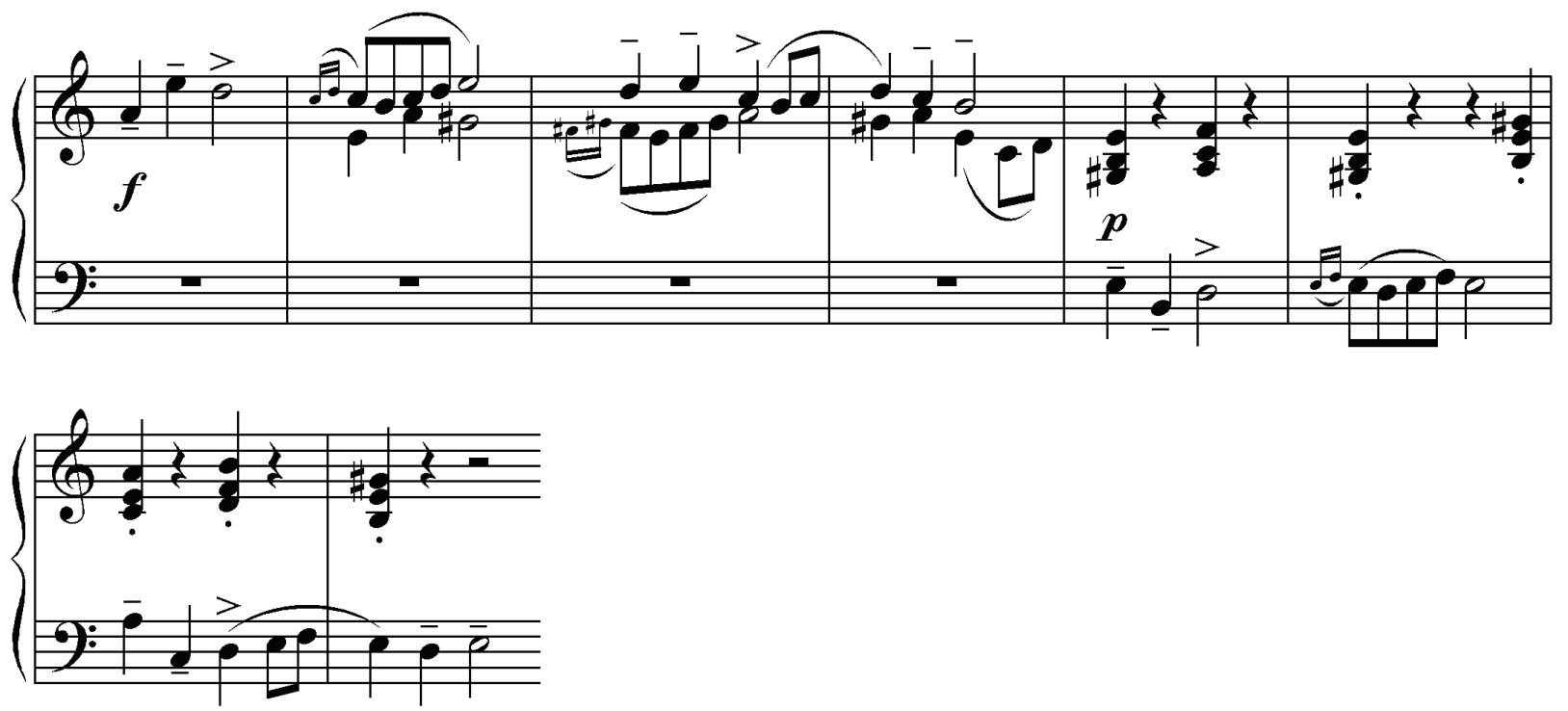

Fig. 18

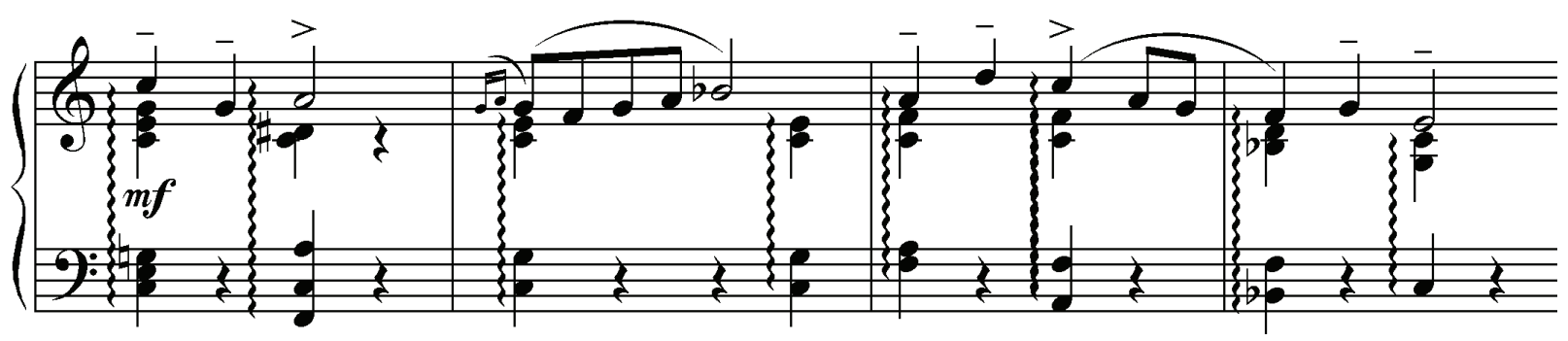

Fig. 19

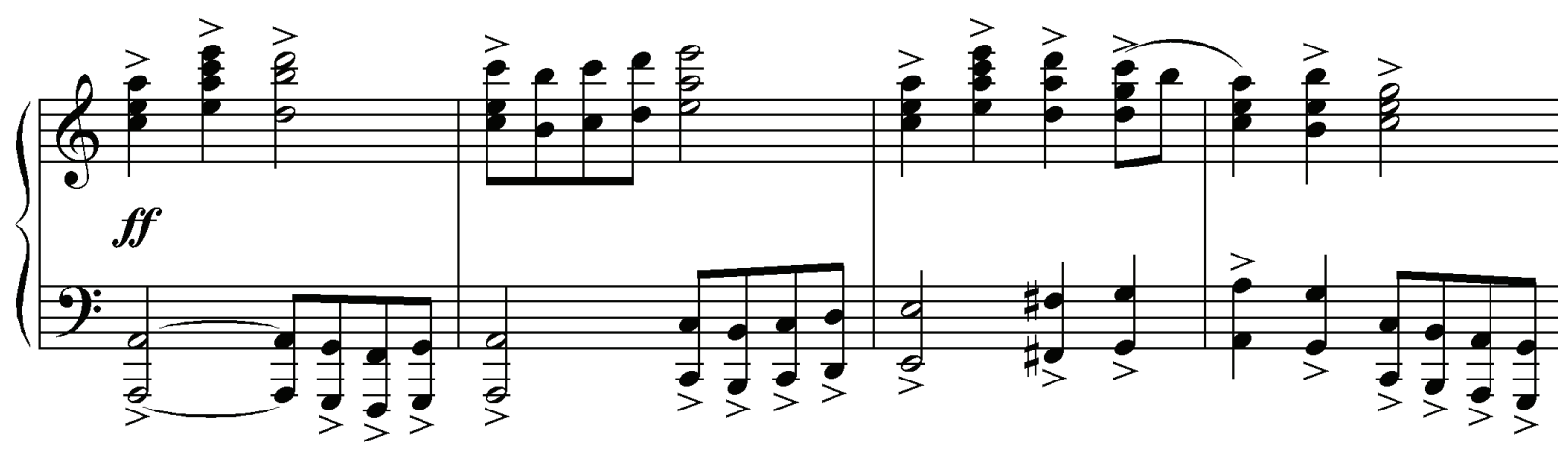

Fig. 20

To compose this episode, Massenet chooses as a theme a song extremely popular in France, "Au clair de la lune" ("In the Light of the Moon"), labeling it in the ballet score not in the traditional way - according to the first line of the first couplet, but by the couplet's last two lines, so concordant in its meaning to the situation developing on the stage: "Ouvre-moi ta porte, pour l'amour de Dieu!" ("Open the door to me, for the love of God!"). By the time Massenet wrote his ballet, this song' had undergone an innumerable quantity of arrangements

\footnotetext{
Some musicians ascribe its creation to Jean-Baptiste Lully, as does Jean Baptiste Duvernoy, who in his four-hand transcription of this theme (in "Les Harmonieuses" opus 313 No. 2) writes the indication: "'Au clair de la lune' (Lully)." However, this assertion has not been proven and presently the authorship of this song is recognized as anonymous.
} 


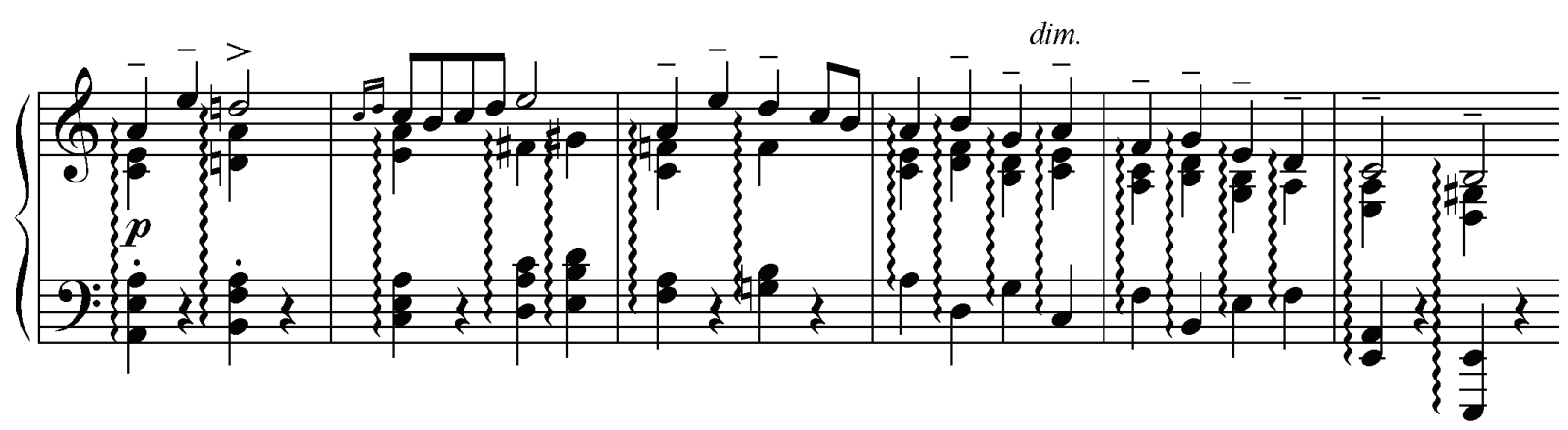

Fig. 21
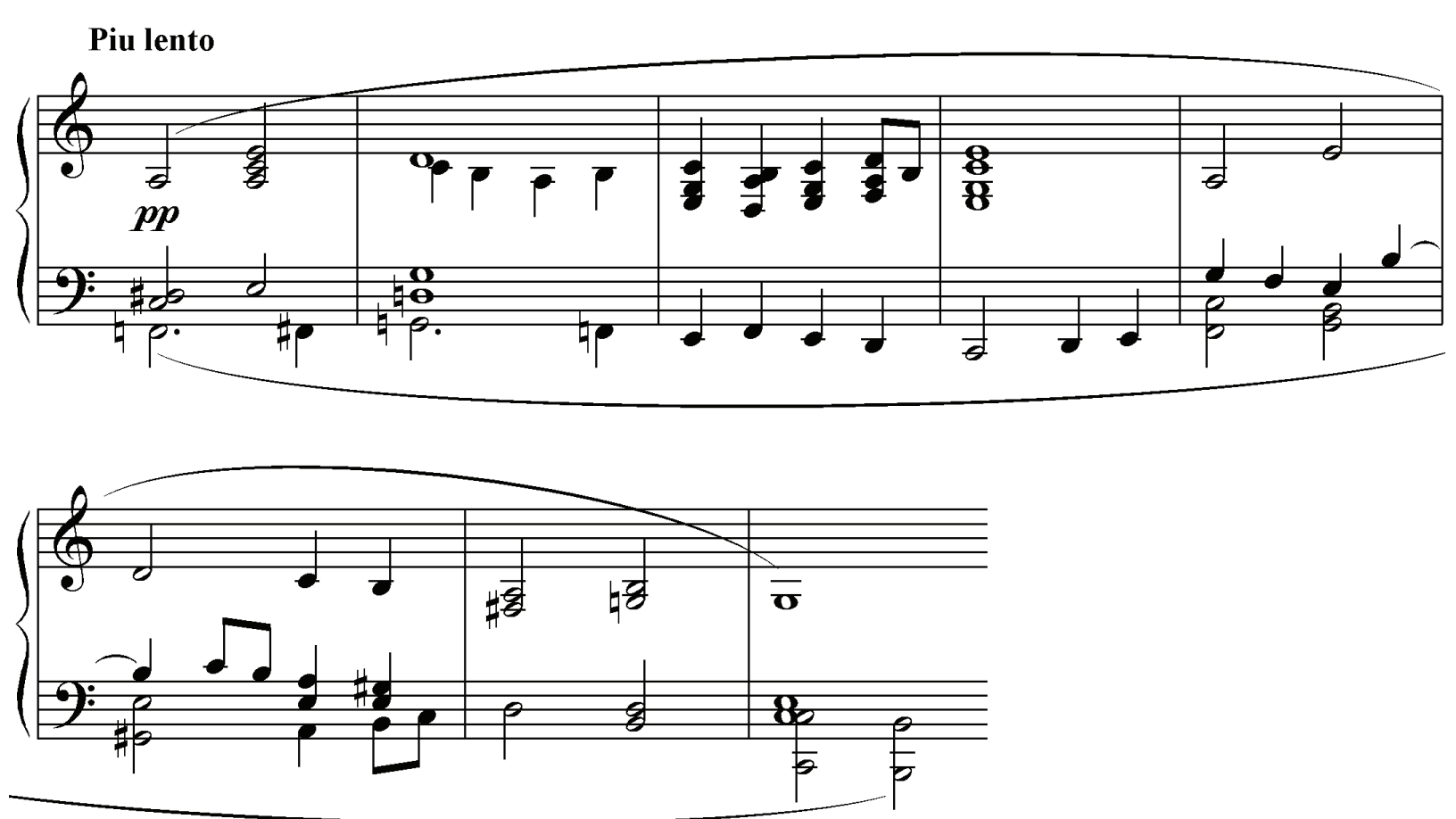

Fig. 22

and became the basis for numerous compositions of different genres. The latter include Matteo Carcassi's Variations for Guitar, opus 7, Arthur Fickenscher's choral arrangement of the song, Ferdinand Hérold's Variations for Piano, opus 19, Frederic Laurent's Variations for Harp, Ignaz Moscheles' Fantasy and Variations for Piano and Orchestra and many other works. In addition, this theme in the guise of a chorale (and with the use of the initial text) was incorporated by Pierre Lanciani into his ballet "Pierrot Macabre" for the sake of creating a funereal procession for Columbine.

Since this fragment is to a partial degree a dance, during the time that the Cricket plays the guitar and dances at this moment, Massenet refrains from arraying a long succession of variations, as was the case in the
Interlude. Here we find a rather laconic succession of the theme and three variations of diverse characters, written out according to the principle of change of textures, types of exposition and tonal "playing" with this simple diatonic melody.

The theme itself is stated as arpeggiato, which is connected with the events happening on stage (here we hear the Cricket playing the guitar) (Fig. 23).

The first variation - in a major key, just like the theme itself - carries a certain affinity with the fourth variation of the Interlude, since it is constructed according to the same principle: the principle of contrapuntal addition to the theme of a voice resembling a "countersubject" (Fig. 24).

The second variation is connected with a reharmonization of the theme, which, while not losing its 

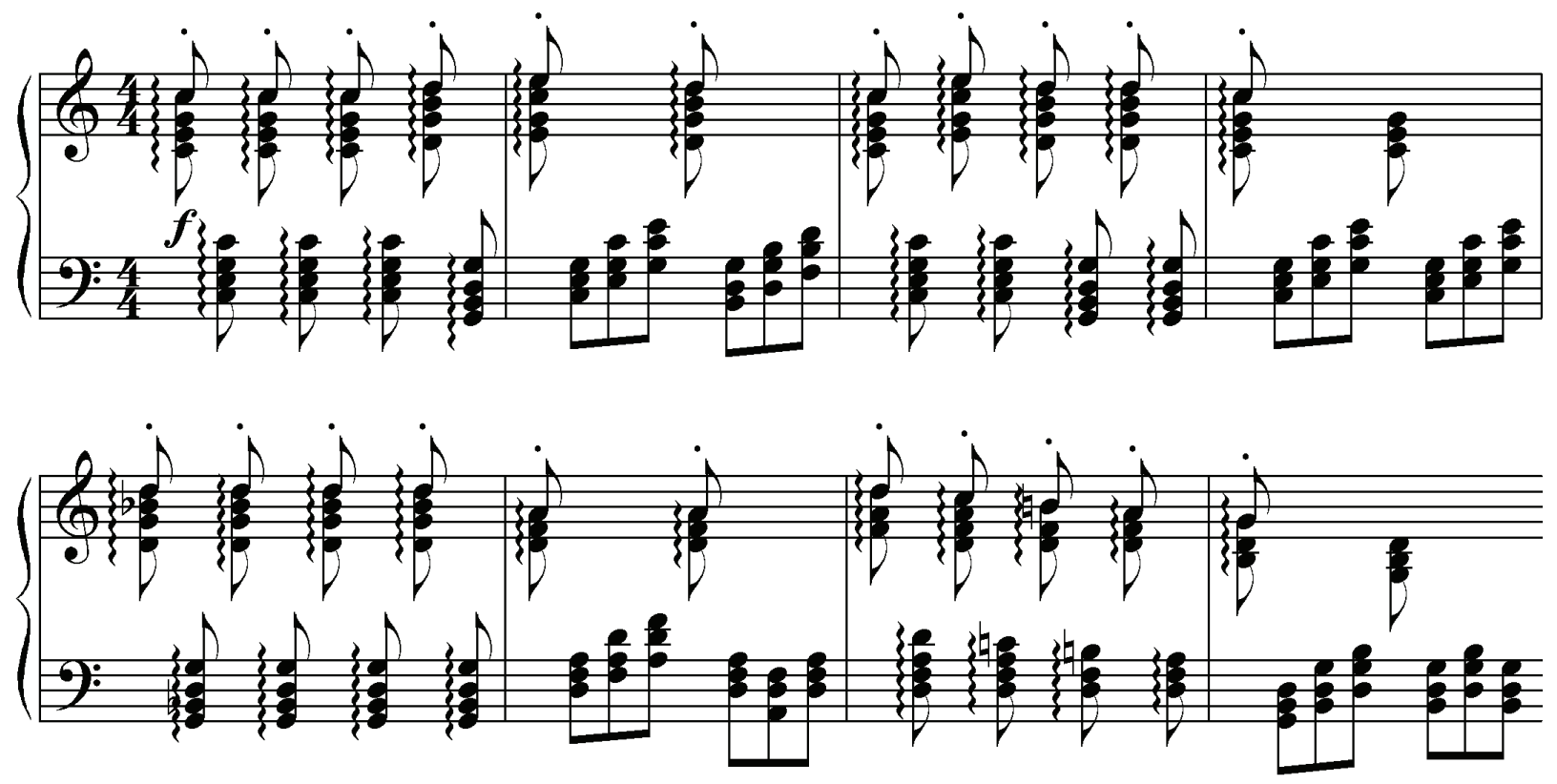

Fig. 23

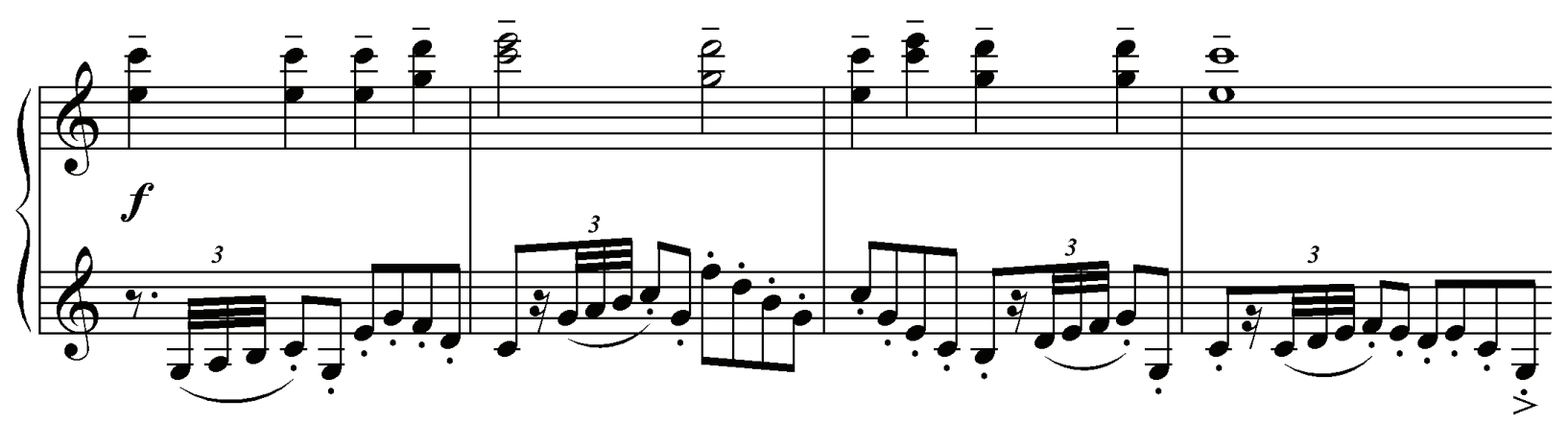

Fig. 24

objective pitch content, is interpreted by the composer as being not in $\mathrm{C}$ major, but in $\mathrm{A}$ minor. Whereas in the first variation there remains a certain sensation of "contrapuntal activity," here we encounter a vestige of classical virtuosity in the figurations accompanying the theme sounding in the low register (Fig. 25).

The third variation, presenting a peculiar climax of the development, returns the major mode, albeit transforming the theme greatly into a vector aspiring to one direction. The fast tempo and characteristic rhythm bring in similarities to a gigue. Moreover, in this variation we once again encounter reminiscences of contrapuntal development, since the theme is stated here in the form of a four-voice imitation in octaves. However, this imitation is not maintained for long precisely, its fourth statement ends up bring "crumpled" and the four-voice counterpoint is "reduced" to a melodic voice, accompanied by accented chords (Fig. 26).

As we have stated before, the extreme shortness of the set of variations can be explained by its inclusion into the action of the ballet, where the application of an unfolded type of musical form is not always possible from a practical point of view'.

The final episode of the ballet, bearing the title "Angels' Lullaby," in which Massenet includes chorus, also deserves separate mention. It cannot be said that such a decision is unique and contradicts fully the genre of ballet per se. Besides the famous "Waltz

And in the cases of one-act ballets, it is also impossible due to the small size of the musical composition. 

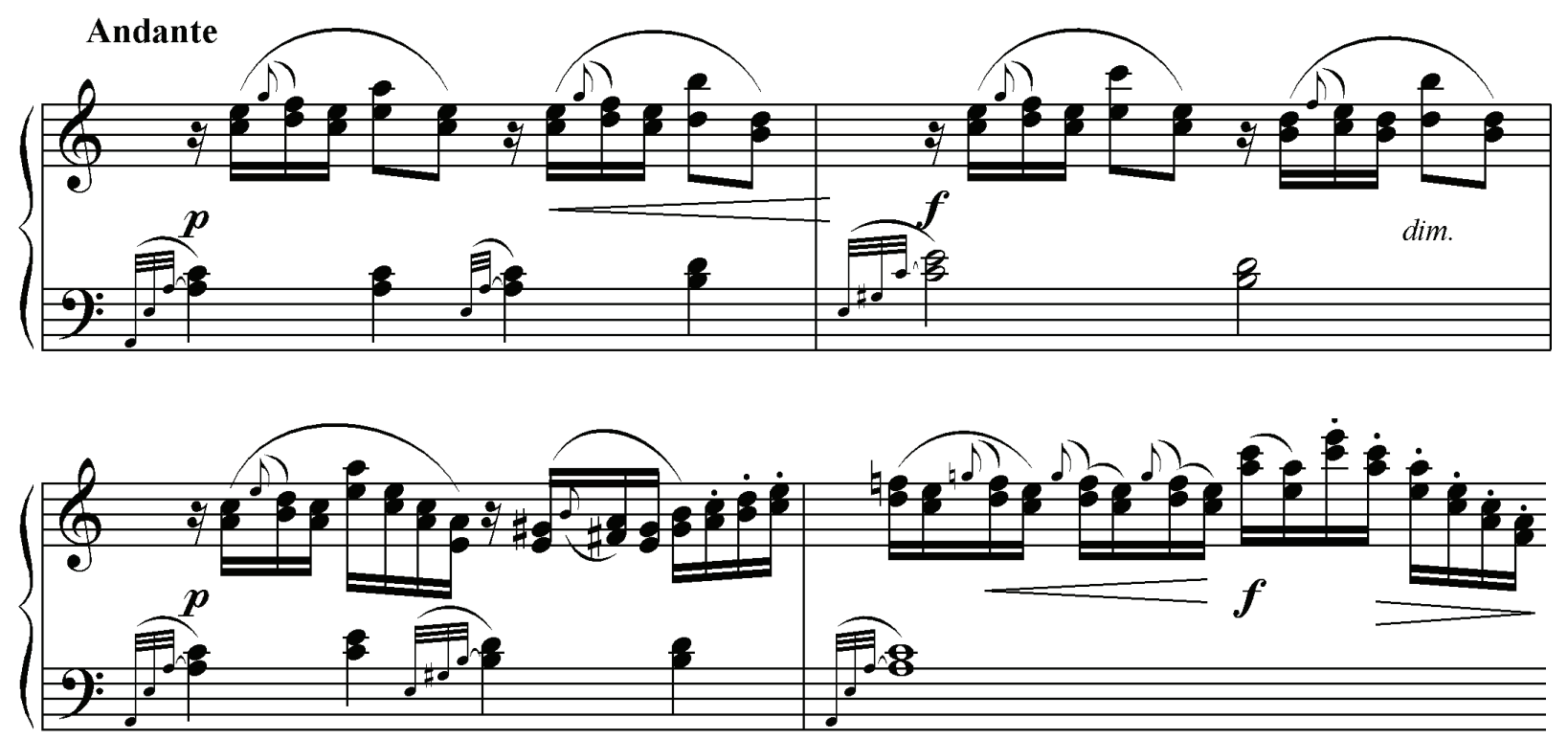

Fig. 25
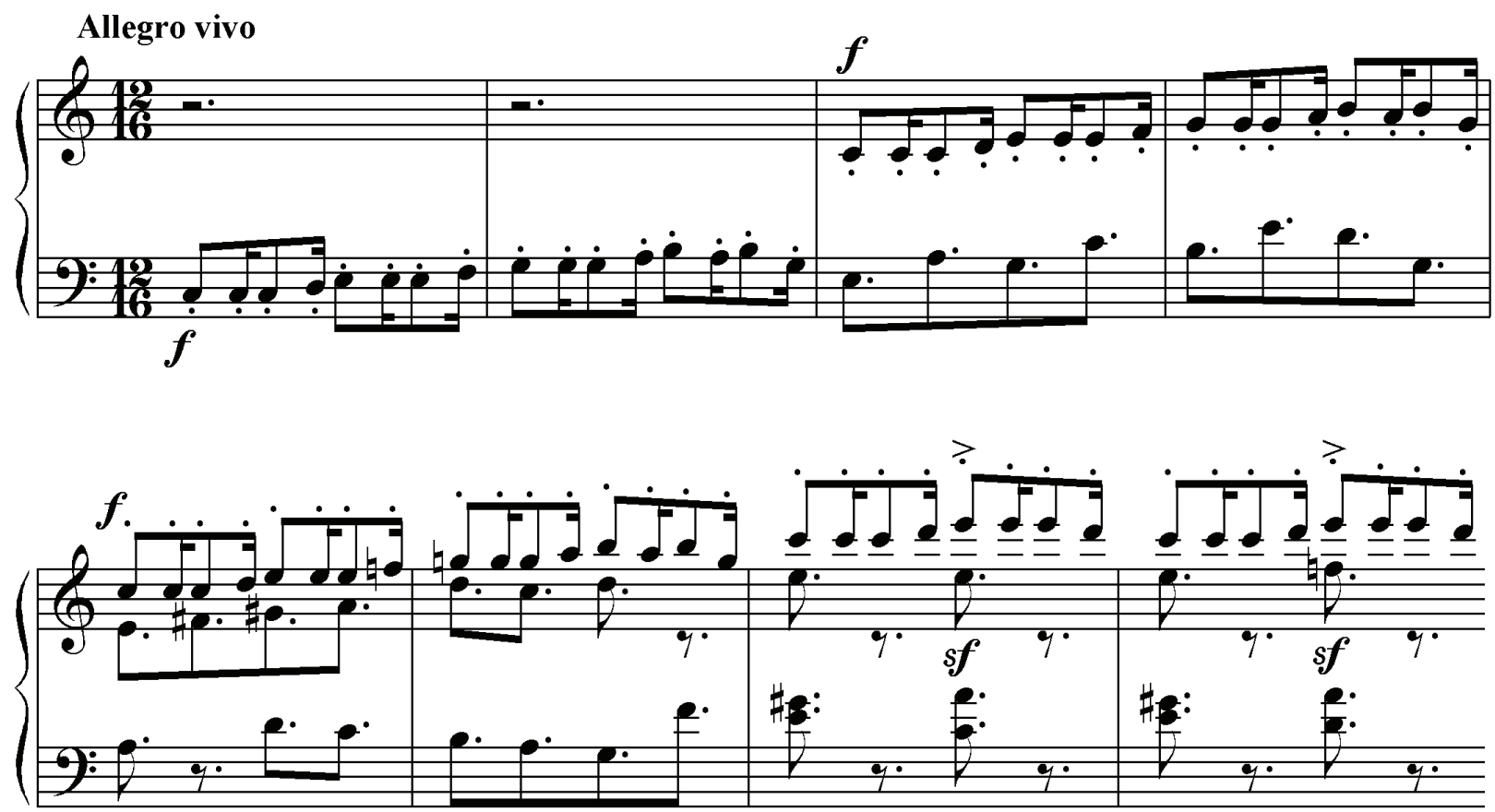

Fig. 26

of the Snowflakes" from Tchaikovsky's ballet "The Nutcracker," it is also not difficult to find such examples among the French $19^{\text {th }}$ century ballets as well. One such example is Louis Ganne's ballet "Frina," written in 1897, in which the hymn to the goddess Venus is sung twice. In addition, the tradition of including choral numbers into ballet, having its origins at the times of creation of the genre of the ballet per se, at various times made the attempt to return into the genre in the $19^{\text {th }}$ century, albeit, each time unsuccessfully. In the ballet "Le Diable Amoureux", in "La Fille de Marbre" and in "Le

«Le Diable Amoureux» — music by François Benoit and Napoléon Henri Reber, production by Joseph Masilier (1840).

"La Fille du Marbre" - music by Cesare Pugni, production by Arthur Saint Léon (1847). 


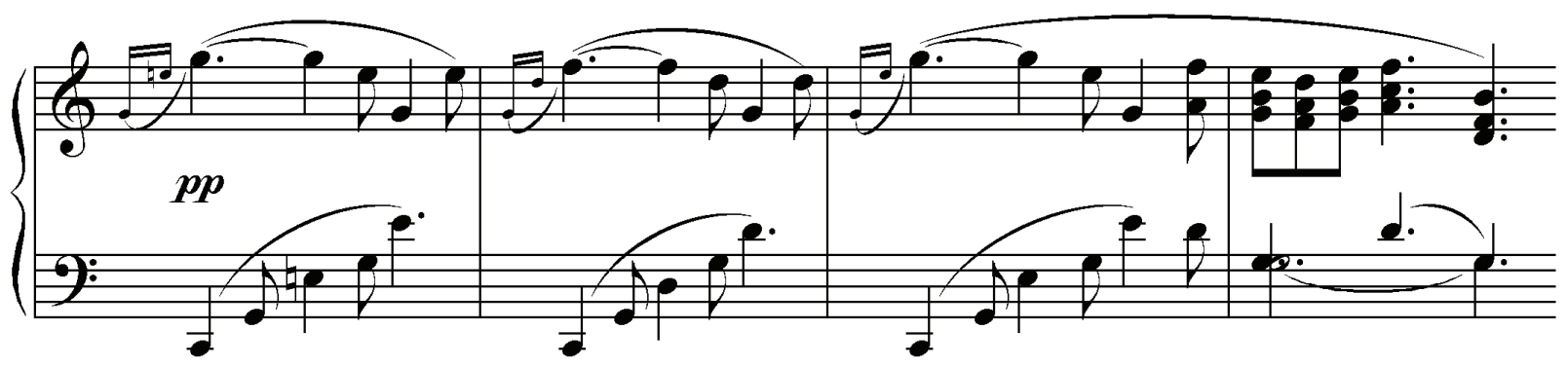

Fig. 27

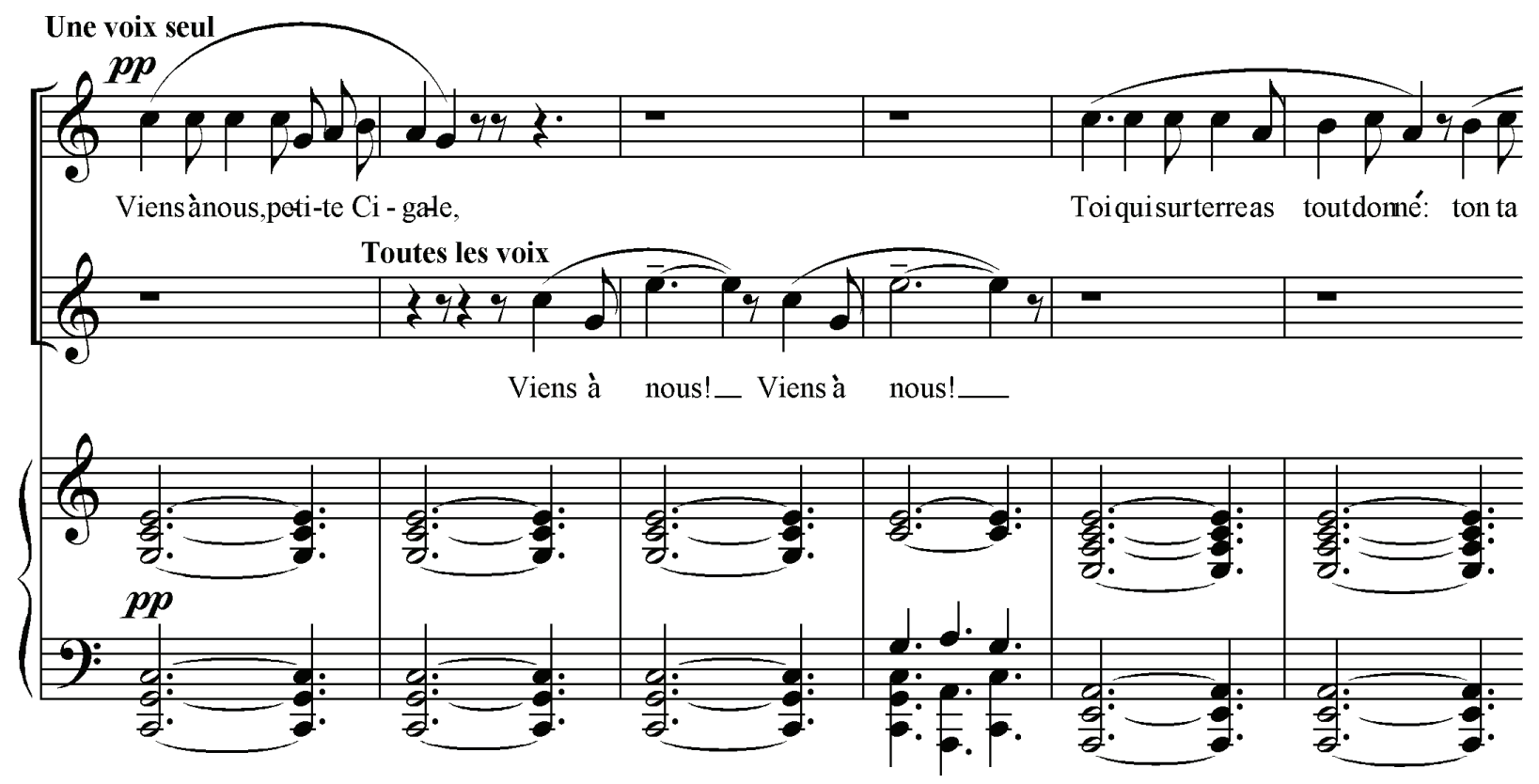

Fig. 28

Corsaire ${ }^{1 "}$ the choral episodes brought into them were "discarded," each time a few days before the premiere performances.

However, in the beginning of the $20^{\text {th }}$ century the incorporation of chorus into ballet became a more frequent occurrence, and even came into regular practice. Vocal parts play a tremendous role in Nikolai Tcherepnine's nallet "Narcissus and Echo" (1911), where it emerges not merely in the guise of sporadic timbre-related color (as it happens in "The Nutcracker," but presents an inseparable constituent part of the very dramaturgy of the composition.

In "La Cigale" the choir of angels appearing at the very end of the ballet presents a peculiar apotheosis, similar to the apotheoses of Romantic ballets, radiant and solemn. As has been said before, here several

"Le Corsaire" - music by Adolphe Adam, production by Joseph Masilier (1856). tendencies are joined together, connected both with the tradition of musical theater per se, as well as with the literary tradition of the Christmas narrative.

Massenet places into his composition a small chorus with a solo voice. The sound of the chorus, soloist and accompanying chorus creates a remarkable contrast to the dramatic episodes pertaining to the events in the Second Act.

The swaying accompaniment that begins the episode, titled "Angels' Lullaby," seems to raise up to the heavens the soul of the misfortunate Cricket, while the theme itself of the Lullaby resembles the hands outstretched to her. This motion of the natural elements towards each other, meeting together at a definite point, clearly demonstrates the dramaturgical meaning of what takes place (Fig. 27).

The solo voice, coming in later, is lyrical and is freed of all the emotional states of anxiety of the past events, while the chorus supporting it is permeated with motives of appeal beckoning to the Cricket. In 
contrast to this, the orchestral part accompanying the vocal episode has a chorale-like texture and is even ascetic in its character. Everything in this episode is meant to portray a different, otherworldly domain, differing in the extreme from the mundane world, both by the melodicism and the overall character of sound' (Fig. 28).

Unlike Masenet's other ballets, "La Cigale" is a work that is connected to the greatest degree with nature, with the sound of nature, the type that could be fathomed by a composer at the beginning of the $20^{\text {th }}$ century.

Devoid of the heaviness and the brilliance of the sound of "Le Carillon" or the vivid Spanish exoticism of "Espada," this ballet appeals to the listener by its clarity and finesse of sound. Frequently making use of very simple harmonic combinations, on the one hand (such as, for instance, in the Dance of the Beloved), while, on the other hand, astounding the ear with an abundance of ninth and eleventh chords, creating the impression of the ringing of strings sounding of their own accord, - all of this creates a remarkable audible effect, which cannot be labeled otherwise than the "effect of harmonic simplicity." Not infrequently for this end Massenet even avoids using the apparent cadence progressions that would sound too precisely and too definitely in this "music of nature" (this happens in the first episode of the Whirling Waltz, already cited above). Due to this "La Cigale" turns out to be a ballet that is intentionally "simple" and "artless." This corresponds very well with both the chosen plot and with the genre of divertimento. However, the definition of "divertimento cannot in any way apply to the painstakingness with which Massenet approached its creation.

Massenet's ballets are, unfortunately, almost completely forgotten at present. Moreover, they did not receive much considerable recognition at the time they were written. It is known that "La Cigale" was produced in 1904 and stood ten performances. When it was revived in 1913, the quantity of the performances given remained the same. It is difficult to say now, wherein lay the reason. It could have been that in 1904 (and, all the more so, in 1913, the year of Sergei Diaghilev's production of "the Rite of Spring") the naïve plot resembling a Christmas story was perceived as something out-of-date. It could have been that at the beginning of the $20^{\text {th }}$ century the public had no wish to watch the history of the interrelations of the Cricket and Madame Ant, searching for some more vivid and bright artistic experience. Then again, maybe its production and performance left much to be desired, since at that time Western European ballet could not boast either of mastering virtuosic dance, or the vividness of the choreographer's solutions. Moreover, in "La Cigale," just as in virtually all the ballets of that time the signs of decline of Western European ballet, demonstrated, first of all, in the absence of any kind of developed male part (the episodic pantomimic roles of the Beloved or the Bank Teller cannot be counted as such).

However, one way or other, it must be acknowledged by us that "La Cigale," just as Massenet's other ballets, deserves more attention that is given to it presently. It goes without saying that we cannot deny that the ballet remains one of the leading genres of Massenet's music. And we must acknowledge the certain fairness of the words of J. (G?) Servier, who in his book on the composer's musical legacy noticed that, for example, "Les Courantes" "is a composition without any special aspirations ${ }^{2}$." However, in the $19^{\text {th }}$ century, and even in the beginning of the $20^{\text {th }}$, ballet was not regarded as a purely musical genre, and could not be evaluated alongside such genres as the symphony or the opera. Exceptions were exceedingly rare, but even they, notwithstanding all their singularity, could hardly compete with compositions of other, "serious" genres.

But, on the other hand, the demands for a ballet score that are equal to the demands for a symphony, present to a great degree the merit of the $20^{\text {th }}$ century ${ }^{3}$. The preceding centuries were characterized by another opinion, and composers who turned to this genre tried to conform to the goals set before them ${ }^{4}$. For this reason, it is not altogether fair to evaluate Massenet's ballets (just as any other example of musical scores of ballets of any epoch) by considering the criteria of symphonic music. in all likelihood, his compositions could receive a revival and attract the attention of choreographers who are weary of creating numerous (and in some cses "tiresome") editions of a limited amount of ballets existing in the repertoire.
Come to us, Cricket, little one, / Come to us! Come to us! / You, who has given everything to the earth — your talent, your beauty, raise your heart up to the sky..." (translated bythe author).

\footnotetext{
Servières G. Jules Massenet // La Musique française moderne.Paris: G. Havard Fils, 1897._- P. 190.

At that, even among the ballet music of the $20^{\text {th }}$ century, not all the musical scores meet such demands.

For a musical score of a ballet it is indispensible to contain dance numbers and to follow a musical dramaturgy — the dramaturgy of the stage, bright characteristics, colorfulness of the orchestration, etc.
} 


\section{REFERENCES (TRANSLITERATED)}

1. Kremlyov, Yu. Jules Massenet.-Moscow: Sovetsky kompozitor, 1969.-

2. Slonimsky, Yu. Dramaturgiya baletnogo teatra XIX veka. Ocherki. Libretto. Stsenarii. [Dramaturgy of 19th Century Ballet Theater. Essays. Librettos. Scenarios. - Moscow: Iskusstvo, 1977. - 343 p.

3. La Cigale. Divertissement Ballet en deux actes de Henri Cain. Musique de J. Massenet._Paris: Au Ménestrel, 1904.- $-88 \mathrm{p}$.

4. Servières G. Jules Massenet // La Musique française moderne._ Paris: G. Havard Fils, 1897._ p. 118-220. 